د · محد بليه حمد العجمي عب

\title{
بيع العربون
}

في الفقه الاسدلامي

(*)

د - - محمد بليه حمد العجمي

المقدمة :

إن الحمـد لله وحـده، والصـلاة والسـلام على مـن لا نبـي بعـده، محمـد بـن

عبدالله، صلى الله عليه وعلى من والاه واستن بسنته إلى يوم الدين. وبعد:

فـالعربون أمـر قديم عـرف مـن العـصور القديمـة، واسـتمر العهـل بـهـ في تشريعات بلدان مختلفة كأداة لضمان تتفيذ العقود والالتزامات.

وقد حرص الإسلام على حفظ الحقوق وأمر بالوفاء بالعقود، ومنها عقد البيع

وما يستلزمه من تعجيل بعض الثمن ما بطلق عليه " بيع العربون ".

وقد حرصت في هذا البحث إلى بيان المقصود بيبع العربون وأصله ونشأته

والفائدة منـه وحكمه في الفقه الإسـلامي، وموقف مجمـع الفقه الإسـلامي الدولي منه، والأصل الذي استتد إليه في قراره بشأنه.

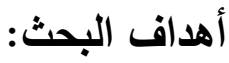

لا شك أن لكل بحث هدفا يسعى إلى الوصول إليه، ونتيجة يبغي تحقيقها،

وقد وضعت في حسباني عند اختيار هذا الموضوع أهدافا أرجو الوصول إليها من

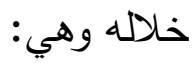

1- بيان المراد ببيع العربون تمهيدا لبيان حكمه في الفقه الإسلامي.

الثريعة الإسلامية، كلية التربية الأساسية - الهيئة العامة للتعليم - النطبيقي

والتدريب- دولة الكويت. 


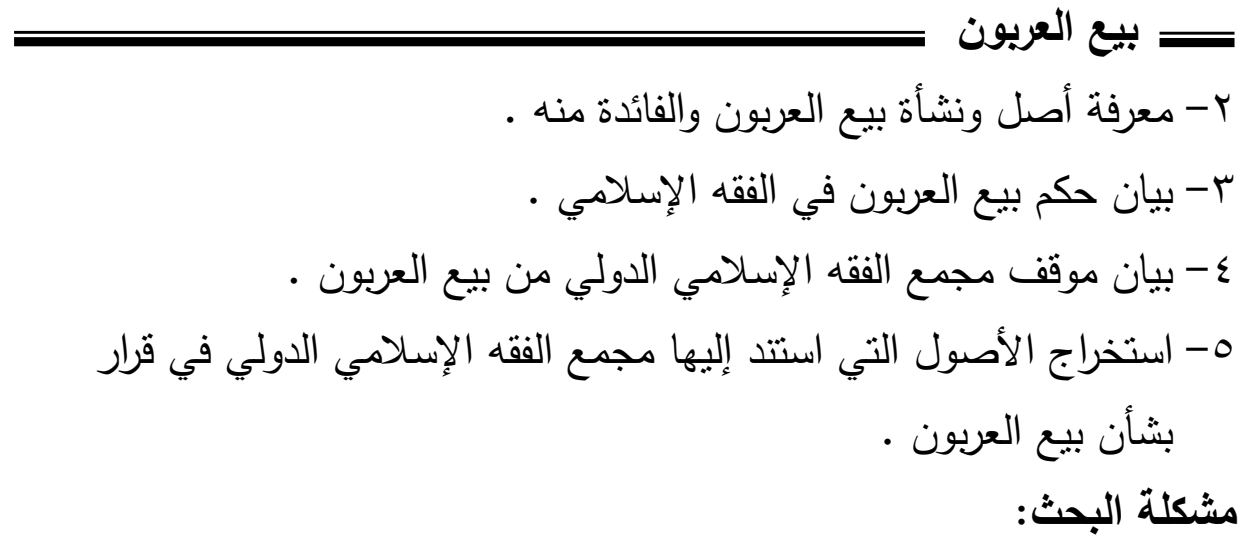

لقد طرحت فكرة البحث عندي تساؤلات عديدة أردت الوصول إليها من دراسة هذا الموضوع، ومن ذلك مثلا: 1- هل وُضِعت حلول حاسمة لبيع العربون في ظل المجامع الفقهيةٌ وهل كانت

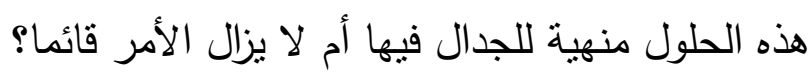

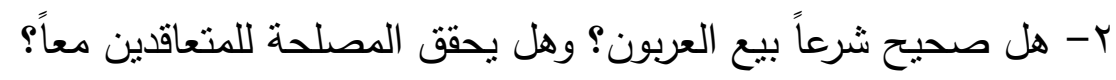

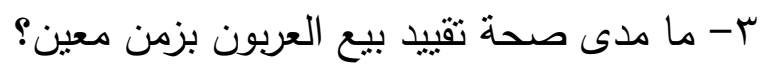

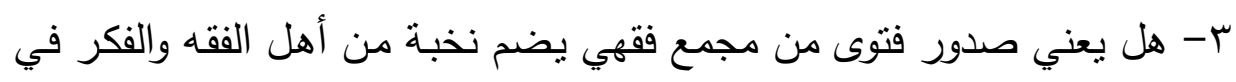

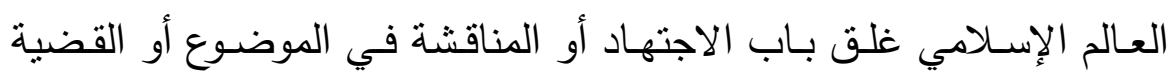

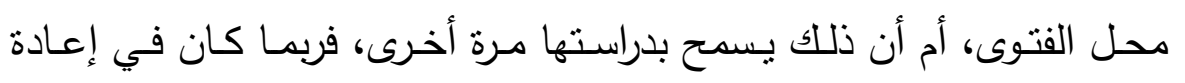

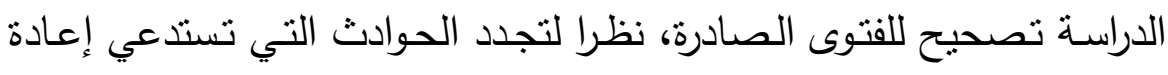

$$
\text { النظر }
$$

الدراسات السابقة في الموضوع: لقد كتب في موضوع بيع العربون رسائل علمية وأبحاث لفقهاء معاصرين ومن ذلك مثلا:

- أحكام بيع العربون وتطبيقاته المعاصرة ، لماجد بن عبدالرحمن الرشيد.

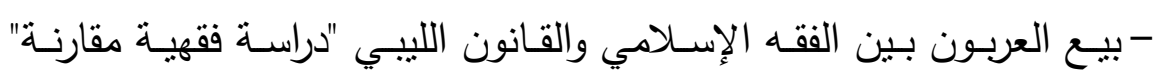

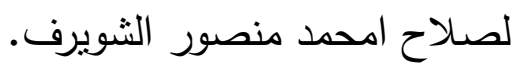


- بيع العربون وتطبيقاته المعاصرة لفردوس خضير .

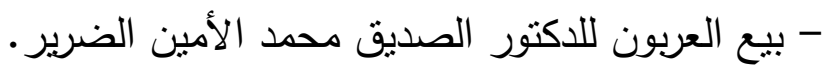
- بيع العربون للاكتور وهبه مصطفى الزحيلي. - بيع العربون للاكتور رفيق يونس المصري. وهذه البحوث تركز في إبراز الحكم الفقهي في بيع العربون باختصار ، ولكن الكن

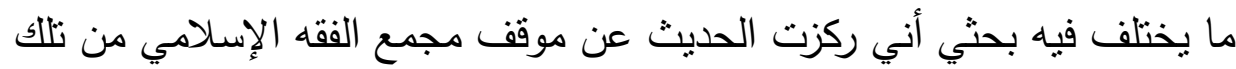
القضية والأصل الذي اعتمد عليه في قراره.

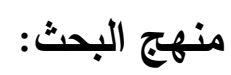

سوف أنبع في هذه البحث المنهج التحليلي، حيث أقوم بتحليل موقف الفقهاء

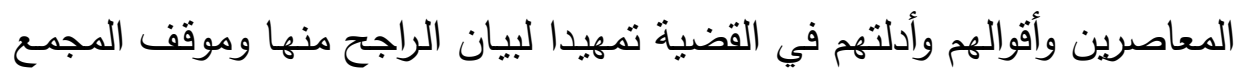
في نلاك القضية والأصل الذي اعتمد عليه، وأتخذ في طريقة الكتابة منهجا موحدا كما هو متبع في البحوث العلمية المقارنة. خطة البحث:

وقد اقتضت طبيعـة الموضـوع أن أقسمه إلى خمسة مطالب على النحو التالي:

المطلب الأول: تعريف بيع العربون وأصله . المطلب الثاني: نشأة بيع العربون وتطوره.

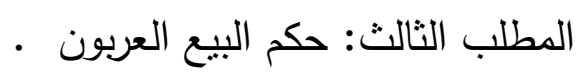
المطلب الرابع : فتوى مجمع الفقه الإسلامي بشأن بيع العربون.

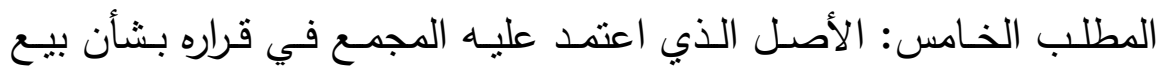




\section{= بيع العريون}

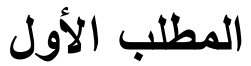

\section{تعريف بيع العربون وأصله}

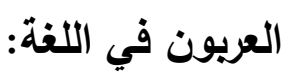

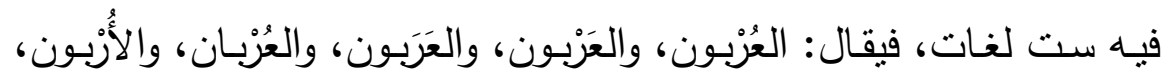

والأَربان، والََََبون، وذلك عن طريق إبدال العين همزة في الجميع.

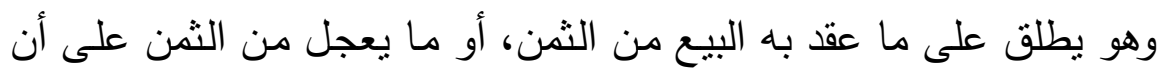

يحسب منه إذا مضى البيع وإلا استحق للبائع.

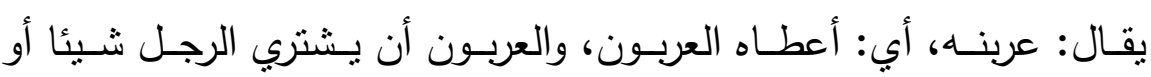

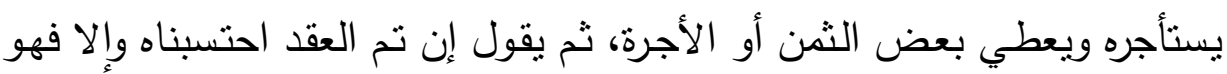

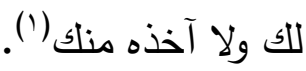

وسبب تسمية العربون بهذا الاسم أن فيه إعرابـا لعقد البيع، أي اصطلاحا

وإزالة فساد، لئلا يملكه غيره باشترائه (ץ).

وفي الاصطلاح:

تعددت تعريفات العربون في المذاهب المختلفة على النحو التالي:

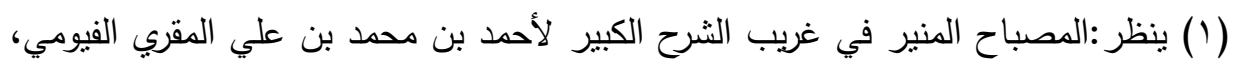

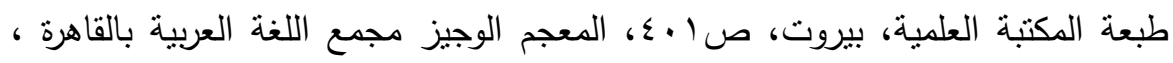

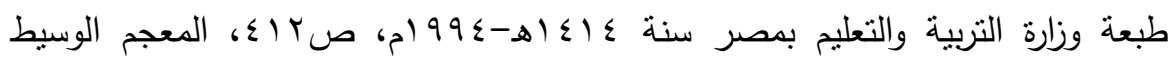

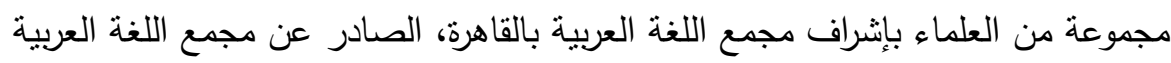

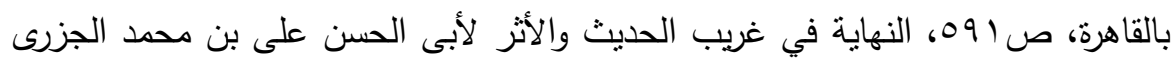

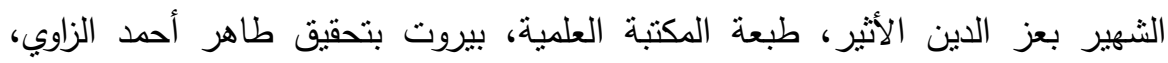

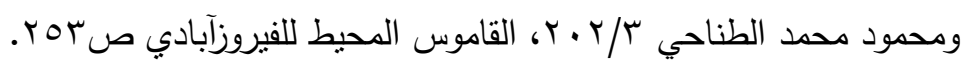

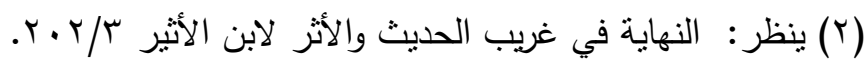




\section{( 1}

يعد المذهب الحنفي أقل المذاهب الفقهية تتاولا لبيع العربون؛ ولذا ندر أن تجد لهم حديثا عنه، أو وضع تعريف له إلا ما جاء عن الشيخ السغدي(') حيث قال: بيع العربـان ويقال الأربـان هو : أن يشتري الرجل السلعة فيدفع إلى البائع دراهم، على أنه إن أخذ السلعة كانت تلك الدراهم من الثنن، وإن لم يأخذ فيسترد

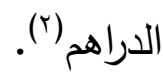

فهذا التعريف قد بين أن العربون مقدم يدفع في عقد البيع على أنه إن تم كان جزءا من الثمن، وإن لم يتم كان من حق البائع، ولكن يؤخذ عليه أنه اقتصر على لى جعل العربون في البيع فقط، لا في غيره من العقود. r

ورد عن المالكية أكثر من تعريف للعربون على النحو التالي: عرفه الإمـام مالك بأنه: أن يشتري الرجل العبد أو الوليدة أو يتكارى الدابة،

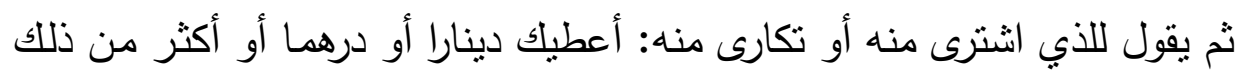

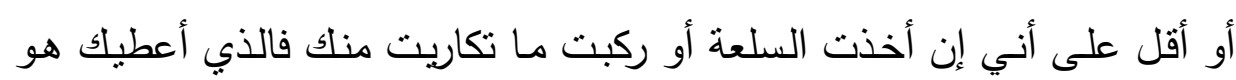
من ثمن السلعة أو من كراء الدابة، وإن تركت ابتياع السلعة أو كراء الدابـة فمـا أعطيتلك لك باطل بغير شيء مناء).

(1) السغدي: أبو الحسن علي بن الحسين بن محمد السغدي، فقيه حنفي أصله من السغد من

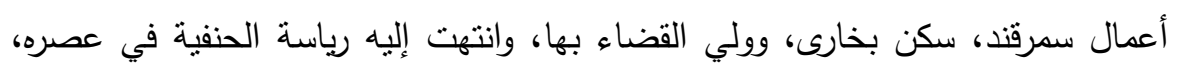

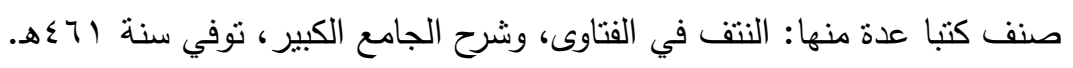

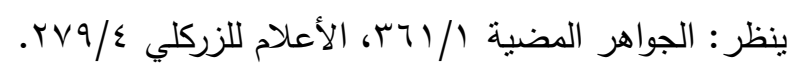

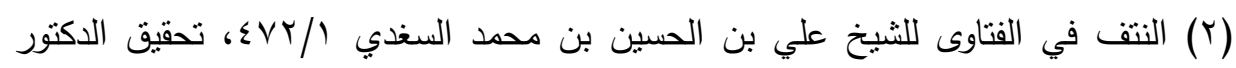

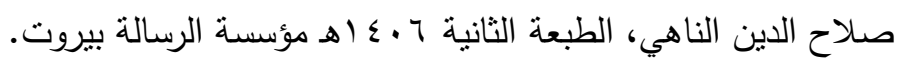

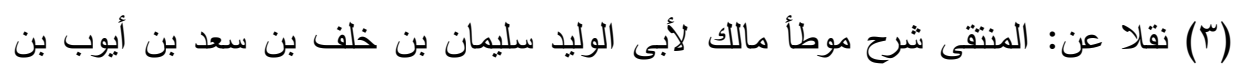

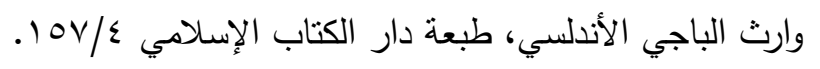


وهذا التعريف اهنت بييان فحوى العربون، إلا أنـه يؤخذ عليه أنه يعد بيانا

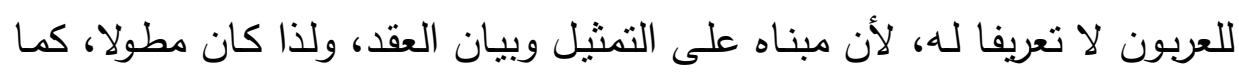

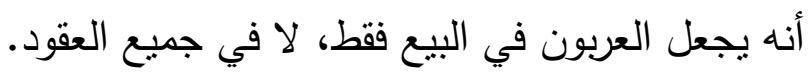

وعرفه بعضهم أيضا بأنه: أن يشتري أو يكتري السلعة ويعطيه، الئهن أي يعطي

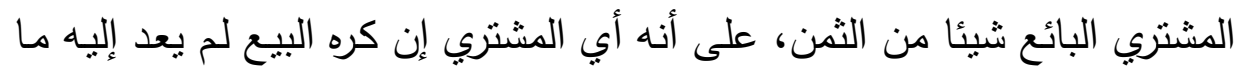

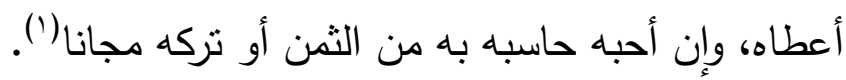

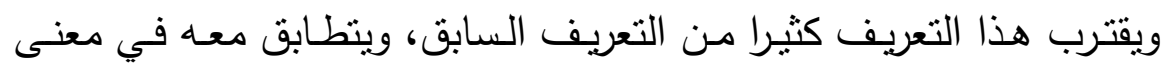
العربون، وكذا في قصره على البيع فقط دون غيره من العقود.

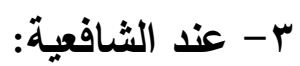
عرفه الثافعية بتعريفات كثيرة، فعرفوه بأنه: أن يشتري سلعة ويعطيه دراهم مثثلا لتكون من الثن إن رضي السلعة وإلا فهبة(؟). وهذا التعريف، وإن كان متميزا باختصاره، إلا أنه اقتصر أيضا على على عقد البيع فقط. وقريب منه القول بأنه: أن يشتري سلعة من غيره، ويدفع إليه دراهم لتكون من الثمن إن رضي السلعة وإلا فهبة("). وهذا التعريف يتطابق مع سابقه تماما في المعنى والمآخذ.

(1) حاثية الدسوقي على الثرح الكبير لهحمد عرفة الدسوقي، طبعة دار إحياء الكتب العربية

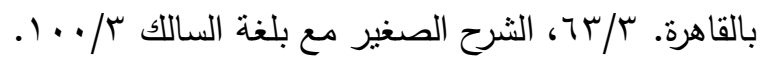

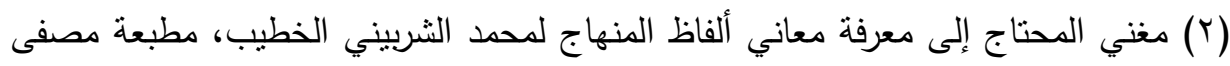

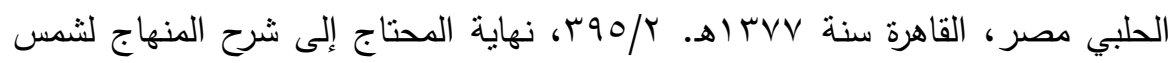

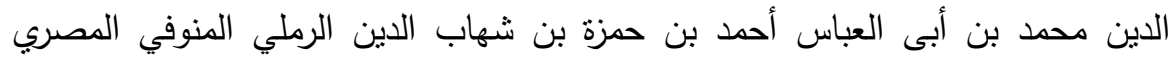

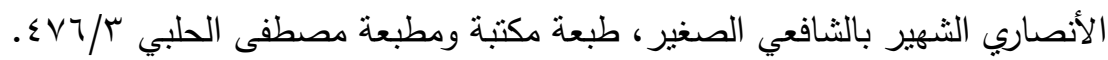

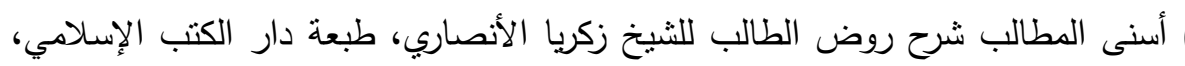

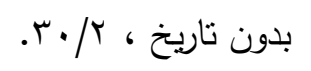


د. • محمد بليه حمد العجمي لــ

وعُرف أيضا بأنه: أن يشتري شيئا ويعطي البائع درهما أو دراهم ويقول: إن

تم البيع بيننا فهو من الثن، وإلا فهو هبة للك('). وهذا التعربف كسابقه تماما في كل شيء.

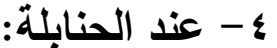

عرف الحنابلـة العربون بأنه: أن يشتري السلعة فيدفع إلى البائع درهما أو غيره على أنه إن أخذ السلعة احتسب به من الثمن، وإن لم يأخذها فذلك للبائع (؟). وعرف أيضا بأنه: أن يشتري شيئا ويعطي البائع درهما، ويقول: إن أخذته

وإلا فالدرهم للك (r).

وهذان التعريفان يقتربان من تعريفات الشافعية السابقة من حيث اقتصارهما

على عقد البيع فقط، واختصارهما، وعدم تتاولهما ما يخرج عن التعريف.

ومن التعريفات السابقة يظهر أن الغلبة في العربون وقوعه في عقد البيع حتى اشتهر بـه، فسمي البيع بالعربون، وإن كان ذلك لا ينفي وقوعه في الإجارة وغيرها من العقود.

ولذا فإن التعريفات السابقة كلها تقريبا تأتي في معنى واحد وطريقة واحدة، ويمكن تعريف العربـون بنـاء على هذه التعريفـات بأنـه: العقد الذي يتفـق فيـه العاقدان على دفع مقدم يكون جزءا من بدله عند تمامه، ومفقودا عند العدول عنه. وقد آثرت أن أقول: العقد، حتى يكون شـاملا للبيع والإجارة، لأنسه بقع في الإجارة كثيرا، وإن كنت قد عنونت المبحث ببيع العربون لاشتهار بذلك حتى غلب

(1) المجموع شرح المهذب لأبي زكريا يحيى بن شرف النووي، طبعة مكتبة الإرشاد بجدة بدون

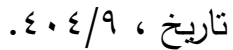

(Y) المغني لموفق الدين أبى محمد عبد الله بن أحمد بن محمد بن قدامة المقدي، طبعة دار

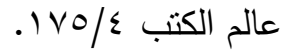

الإنصاف في معرفة الراجح من الخلاف على مذهب الإمام أحمد بن حنبل لعلاء الدين

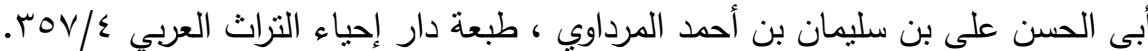




\section{= بيع العربون}

عليه، وقد بينت في التعريف أن العربون يكون جزءا من بدل العقد إذا تم منتجا

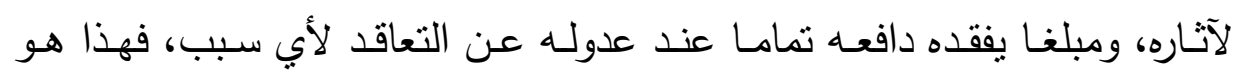
العرف المعمول به في حال التعاقد بالعربون. * * 
د د محمد بليه حمد العجمي لبـ

المطلب الثاني

\section{نشأة بيع العربون وتطوره}

إن العربون أمر قديم عرف منذ العصور القديمة، حيث ثبت العمل به في عصر الفينيقينين قبل الميلاد بأربعـة عشر قرنـا، فقد كان صـاحب العمل بدفع للأجير مبلغا من النقود يكون ضمانا له، فإذا تركه صـاحب العمل استوفى أجره منهه، كما ظهر ذات المصطلح في الشريعة العبرية، حيث استخدم في الضمان وفي الإثبات كوسيلة للوصول إلى ذلك.

وظهر العمل بالعربون أيضا في تشريعات بلاد ما وراء النهرين كأداة لضمان تتفيذ العقود والالنزامات، حتى إن الخاطب كان يلتزم في مرحلة أولى بأن يدفع إلى خطيبته مبلغا بطلق عليه الترخاتو، أو المهر ، وكان الزواج يأخذ شكل الثراء، فإن عدل الخطيب عن ذللك فَقََ ما دفعه إلى خطييته أو والدها('). وعن طريق الفينقيين انتقل العمل بالعربون وفكرته أيضا إلى التشريع اليوناني القديم، فظهرت العقود التي تحمل فكرة العربون في البيع والإجارة، وعرف ذللك منذ القرن الثالث عشر قبل الميلاد، وكان العربون يدفع بواسطة المشتري للبائع، وإذا عدل المشتري عن البيع فإن البائع يكون محميا من مخـاطر هذا العدول عن طريق العربون.

ثم دخل العربون إلى القانون الروماني عن طريق الثرائع الثرقية، حيث كان العربون معروفا في شعوب البحر المتوسط، وانتقل منها إلى الرومان عبر الروافد التجاريـة المختلفة، ولكن للعربون في القانون الروماني تطبيقات عديدة، وظهرت أهميته لديهم في عقود مختلفة منها البيع والزواج وغيره(؟).

(1) ينظر: العربون بين الفقه الإسلامي والقانون المدني، دراسة مقارنة للاكتور ياسر محدد

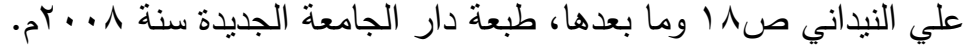

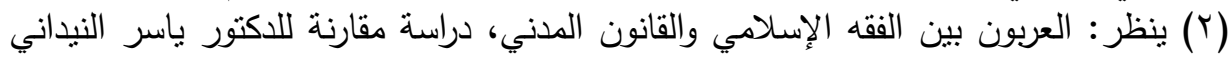

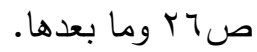


كما عرف المصريون القدماء فكرة العربون، وجاءت عقود كثيرة أبرمت في لئن

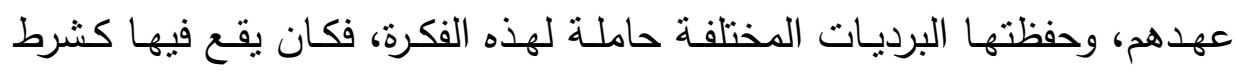

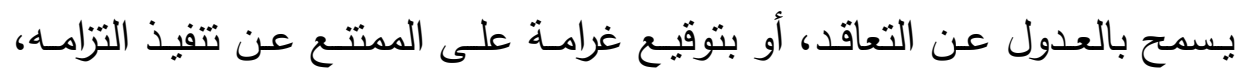
مقتبسين إياه من الإغريق القدماء) (1). أما عند العرب قبل الإسـام فقد كان اشتراط العربون في اليبع والإجارة وفي

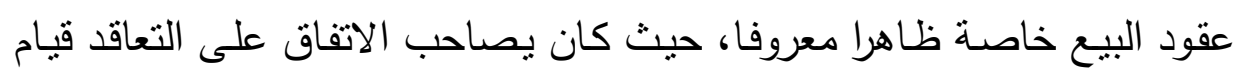

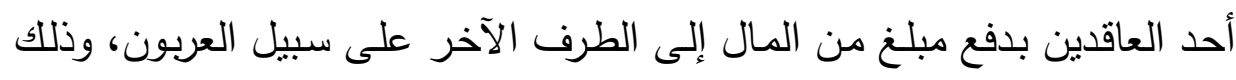

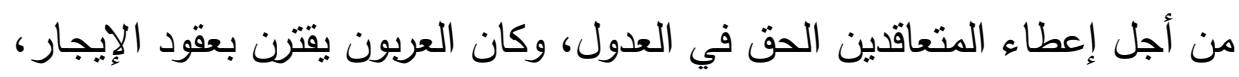

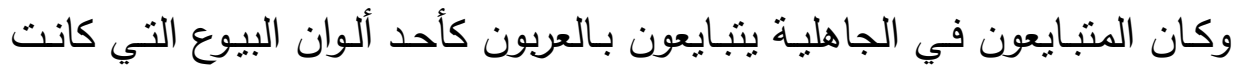

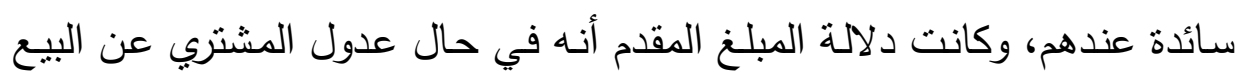

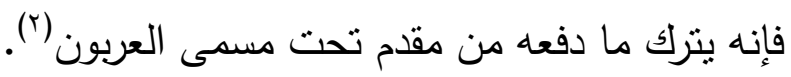

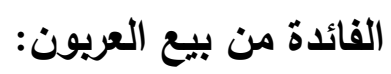

لقد ولدت فكرة بيع العربون منذ قديم الزمان كما ذكرت، وقد حقق فائدة مهمة

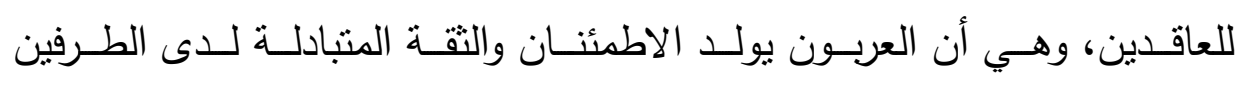

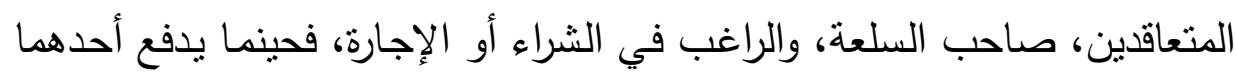

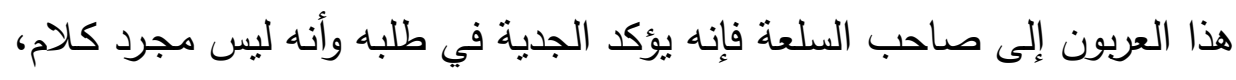
وبذلك يطئن الطرفان المتعاقدان أن العملية تسير في مسارها الصحيح(").

(1) ينظر: تاريخ القانون المصري للاكتور عبد المجيد الحفناوي صعالا لا، طبعة مؤسسة

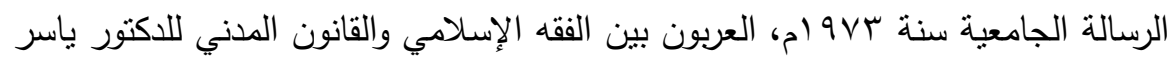

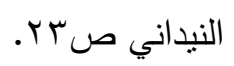

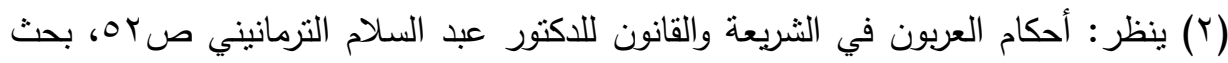

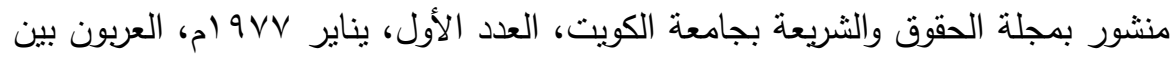

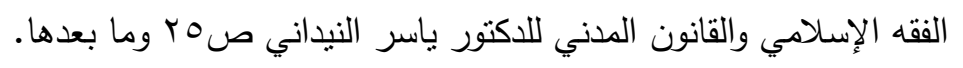

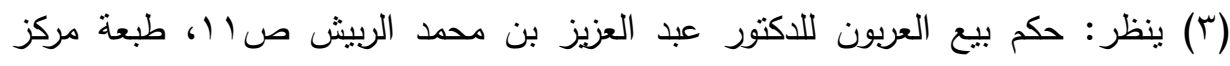

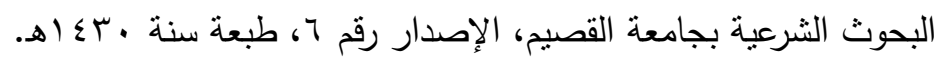


د · · محمد بليه حمد العجمي حس.

فالعربون إذن يحقق فائدة لكل من العاقدين، حيث يطمئن البائع إلى قبول المشتري وسيره في التعاقد حتى النهاية، وبطمئن المشتري إلى قبول البائع للعقد، فيمكنه التصرف في باقي الثمن بأي طريق، فقد يكون المشتري عاجزا عن دفع كل الثنن، ويحتاج إلى وقت لتجهيزه، بل قد يبيع شيئا من أمواله لتوفير الثمن، ومن هنـا يكون قبول البائع للعربون دلالـة قويـة على تمـام التعاقد، فيمضي في أموره حتى النهاية، وسوف تتضح الحكمة أكثر ببيان حكم العربون على ما يأني تفصيله بإذن الله تعالى في المطلب التالي. * * * 


\section{المطلب الثالث}

\section{حكم البيع بالعريون}

إذا أمعنا النظر في تعريفات العربون السابقة نجد أن بعض الفقهاء عبر عن لئن

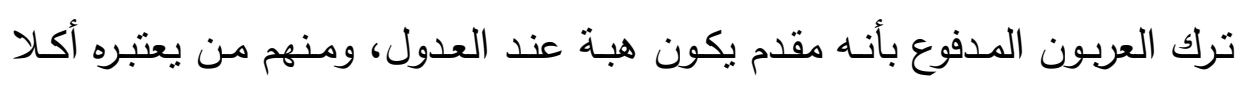

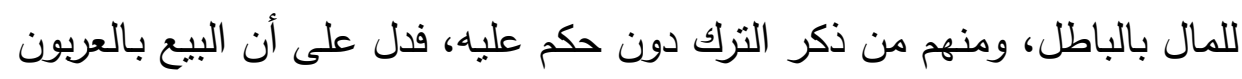
فيه خلاف بين الفقهاء، حيث اختلفوا في حكمه على ثلاثة أقوال:

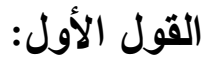

ذهب جمهور الفقهاء من الحنفية(1)، والمالكية(Y)، والثافعية(r)، والإمام أحمد الهد

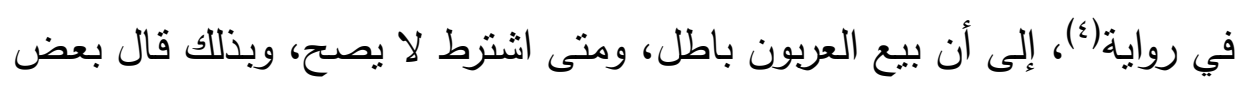

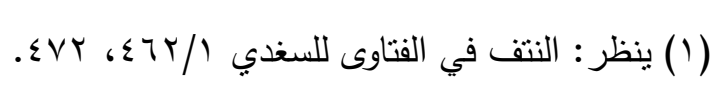

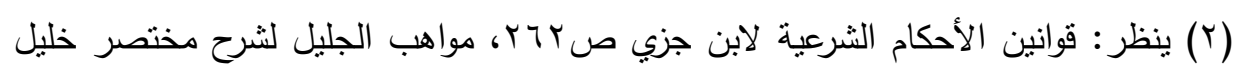

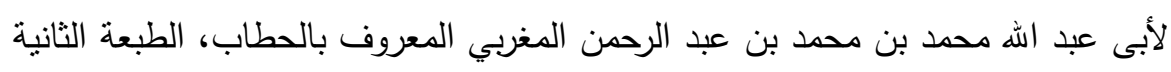

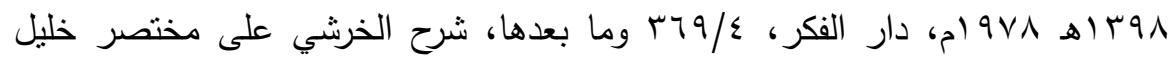

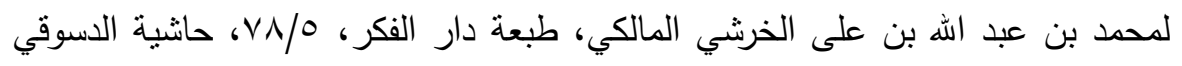

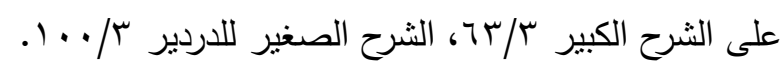

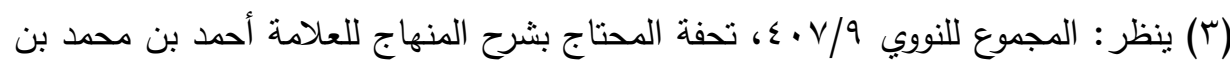

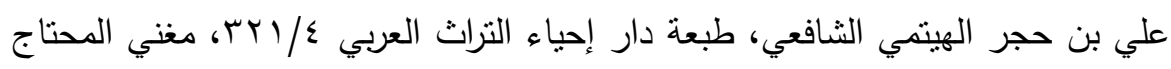

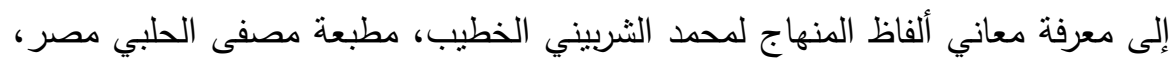

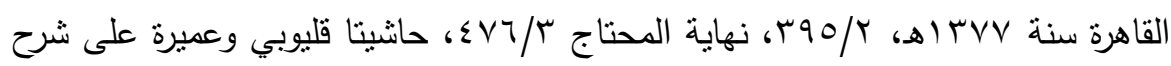

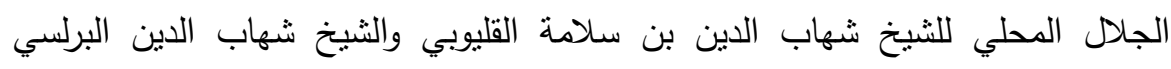

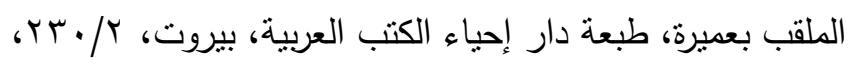

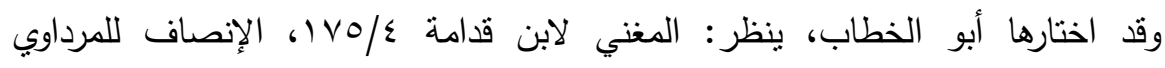
$. \mathrm{rON} / \varepsilon$ 


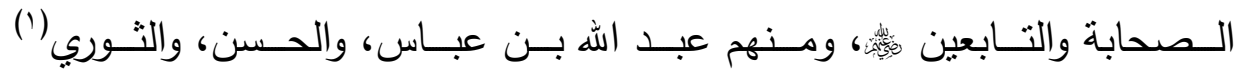

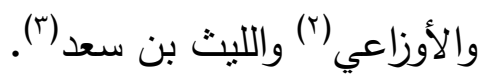

(1) الثوري: أبو عبد اله سفيان بن سعيد بن مسروف الثوري الكوفي، ونسبته إلى ثور بن عبد

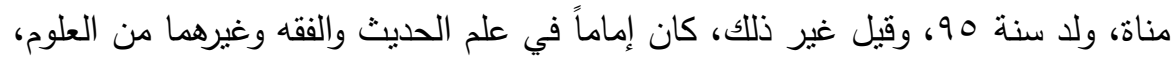
وأجمع الناس على دينه وورعه وزهده، وهو أحد الأئمة المجتهدين، وتوفى بالبصرة في

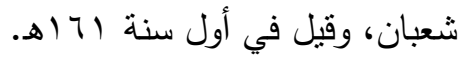
ينظر: تهذيب الكمال في أسماء الرجال لجمال الدين أبى الحجاج يوسف المزى، الطبعة

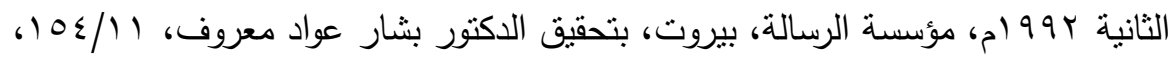

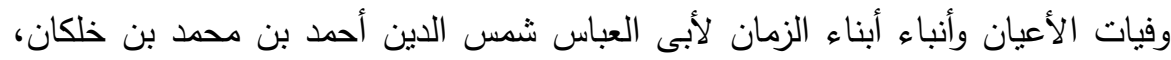

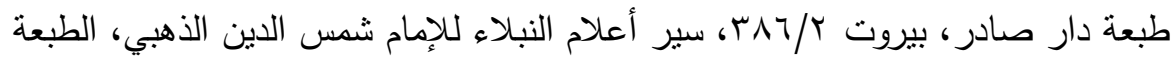

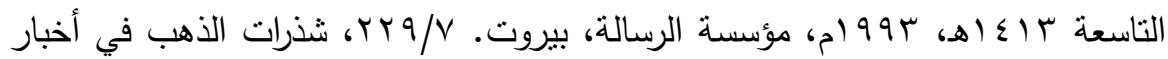

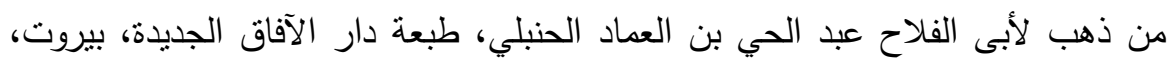

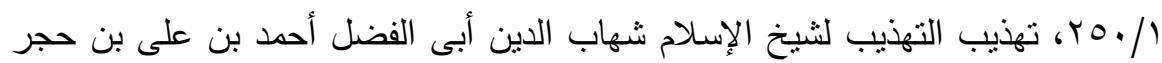

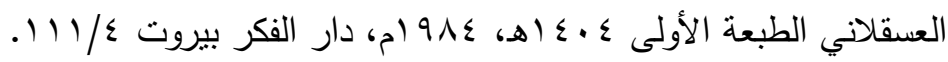

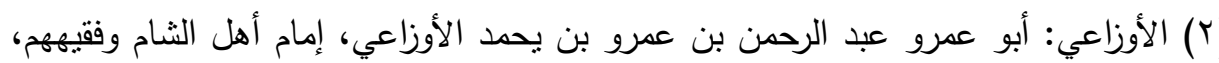

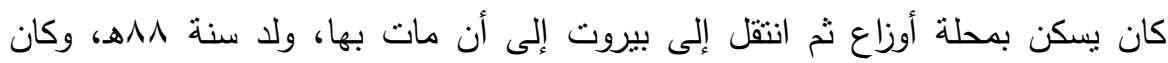

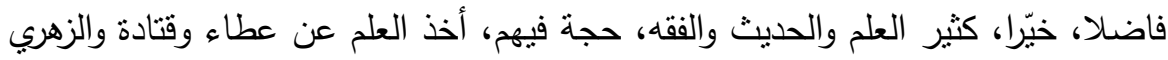
وابن سيرين وغيرهم، وتعلم على يديه خلق كثثر منهم شعبة والثوري والإمام مالك وابن

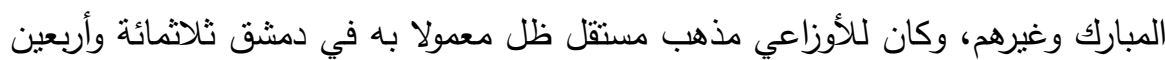

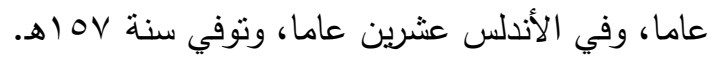

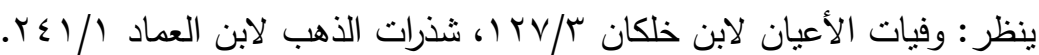
(r) الليث بن سعد: أبو الحارث الليث بن سعد بن عبد الرحمن الفهمي المصري، أحد الأعلام في الفقه، وصاحب مذهب مستقل لكنه اندثر بعد وفاته لعدم نشر تلاميذه لمذهبه، ولد سنة النة

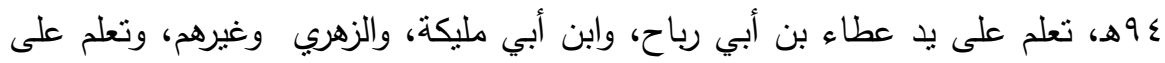

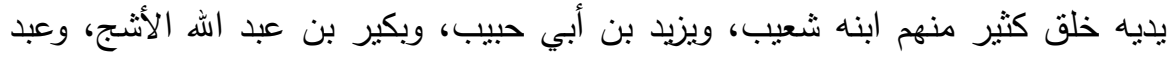
الرحمن بن القاسم، وغيرهم، وتوفي في شعبان سنة ل V الهـ.

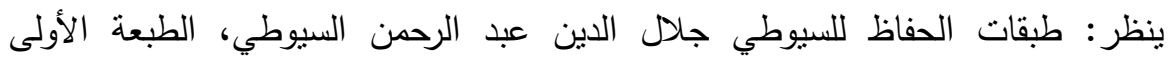

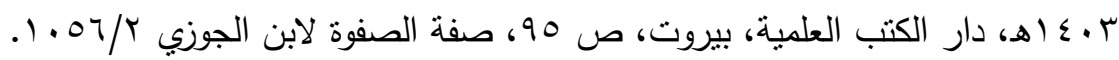


واستنلوا على ذللك بما يلي:

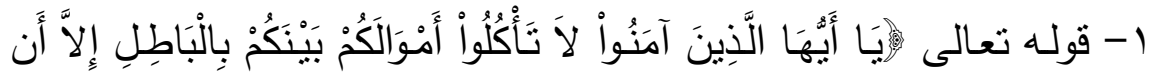

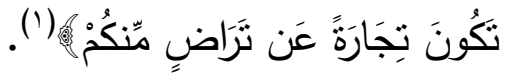

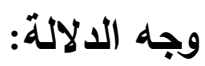

أن اله -تعالى - نهى عن أكل أموال الناس بالباطل واستثىى التجارة عن تراض، والبيع بالعربون ليس تجارة عن تراض، فكان من أكل المال بالباطل، فكان

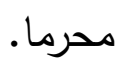

\section{ويناقش هذا:}

بأن الآية أجازت التجارة عن تراض، والبيع بالعربون نوع تجارة عن تراض، وقد خلا من الأمور المحرمة، فكان مباحا.

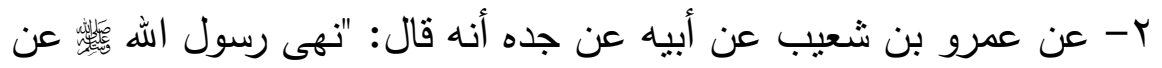

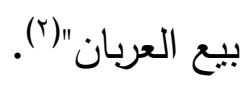

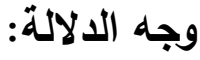

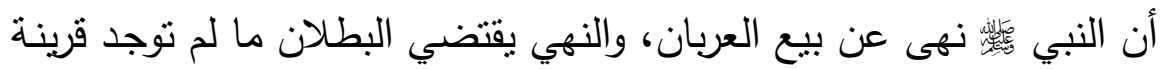
صارفة، ولا قرينة، فدل على أن بيع العربون باطل.

$$
\text { (1) سورة النساء من الآية رقم } 9 \text { ب. }
$$

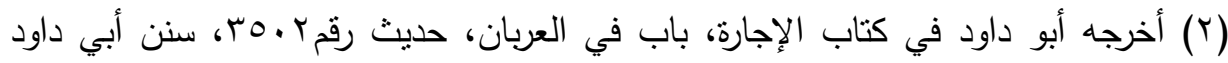

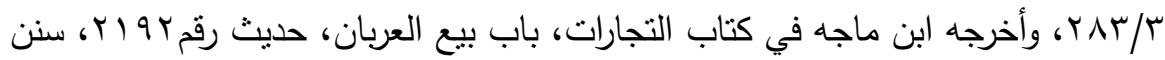

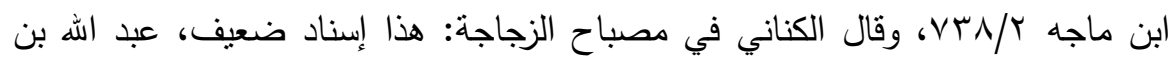

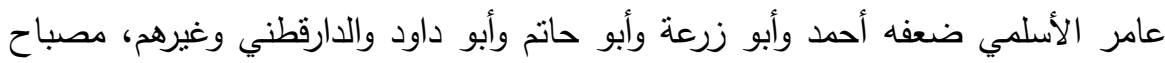

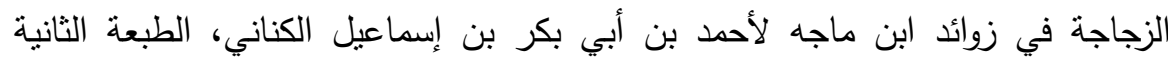

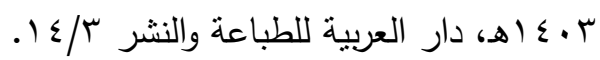


ونوقش هذا:

بأن الحديث ضعيف، لأن في إسناده رجل لم يسم، ومثل هذا لا يحتج به،

كما أن الروايات الأخرى لم نسلم من ضعف، فقيها عبد الله بن عامر الأسلمي (') وهو ضعيف لا يحتج به (r).

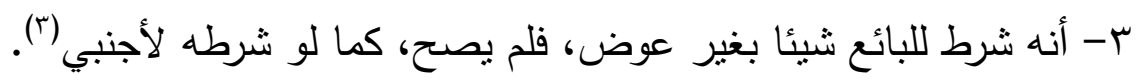

$$
\text { ويناقش هذا: }
$$

بأن العربون شرط للبائع مقابل ما يقع لله من ضرر بسبب المشتري، فكان

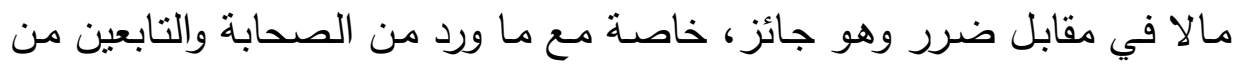

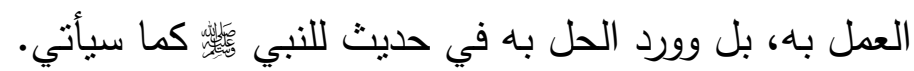

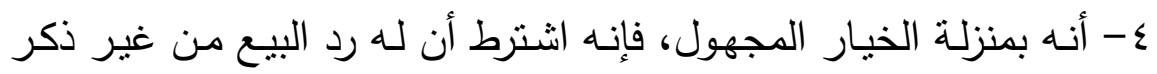

مدة فلم يصح، كما لو قال: ولي الخبار متى شئت رددت السلعة ومعها درهما (؛). ويناقش هذا:

بأن الجهالة المذكورة هنا يمكن رفعها عن طريق تحديد مدة معينة بلزم بعدها

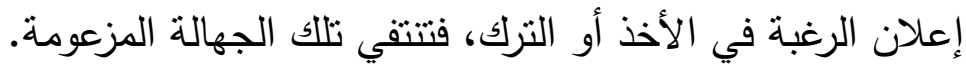

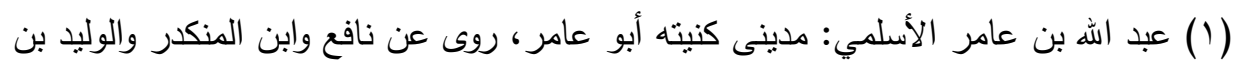

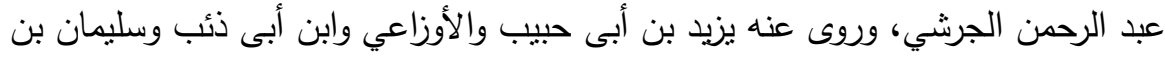

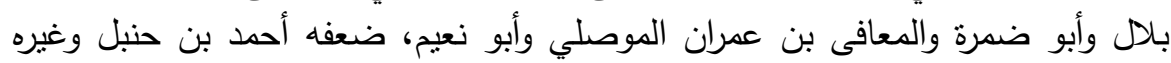

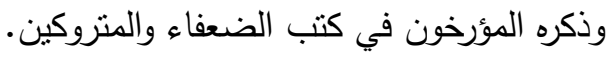

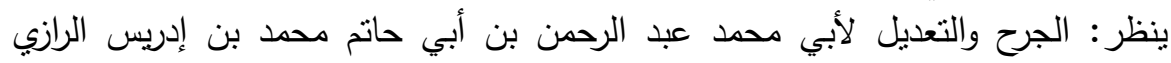

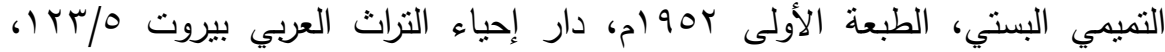

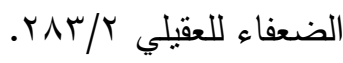

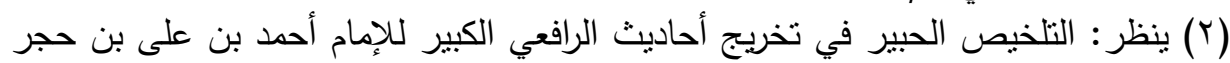

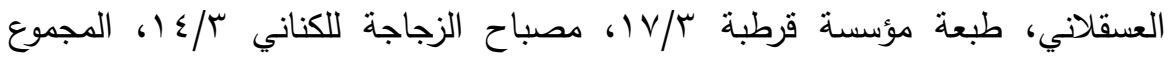




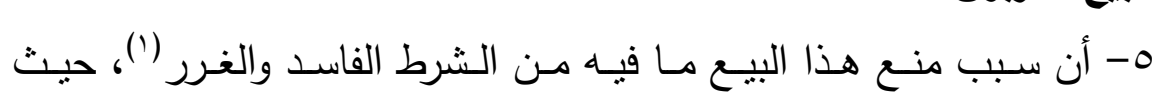

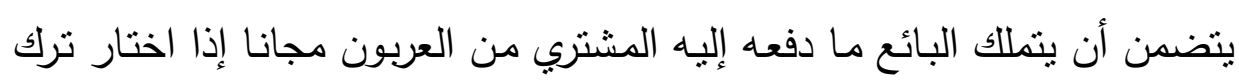

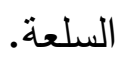

\section{ويناقش هذا:}

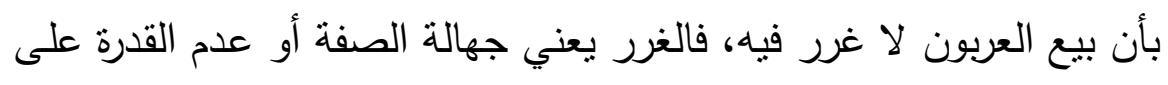

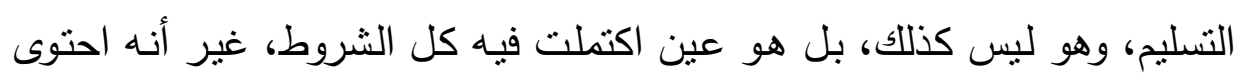

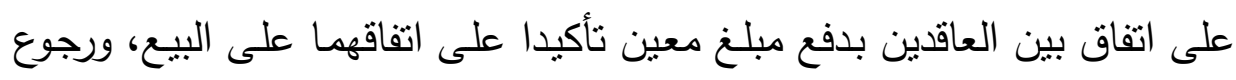

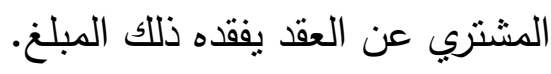

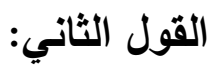

ذهب الإمام أحمد في رواية(؟) إلى أن البيع بالعربون صحيح وجائز شرعا،

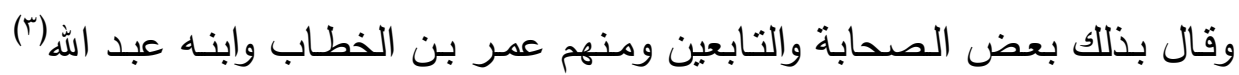

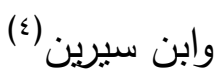

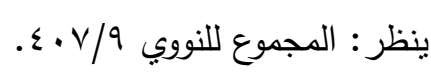

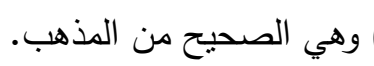

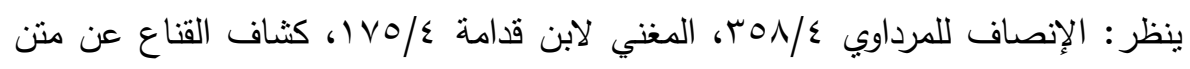

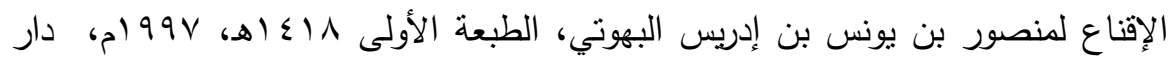

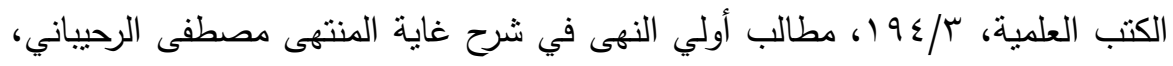

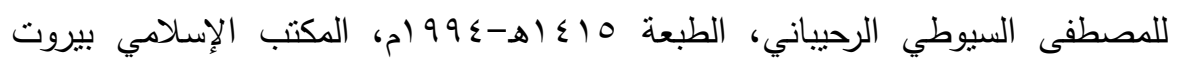

$$
. v V / r
$$

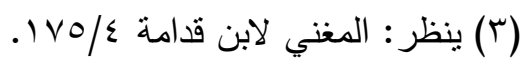

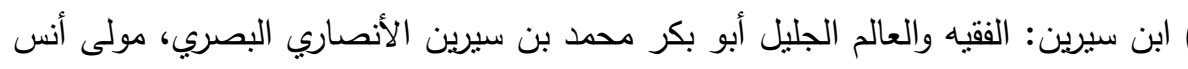

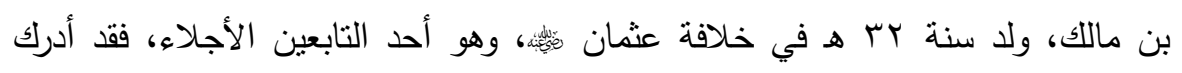

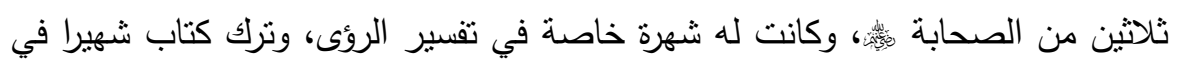

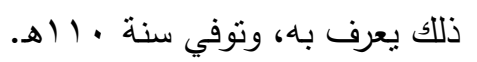

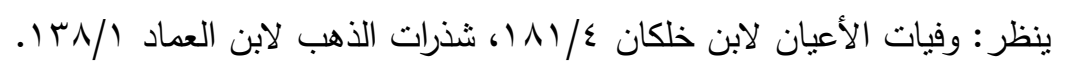




$$
\begin{aligned}
& \text { ومجاهد(') ونافع بن الحارث(r) وزيد بن أسلم(r). } \\
& \text { واستدلوا على ذلك بما يلي: }
\end{aligned}
$$

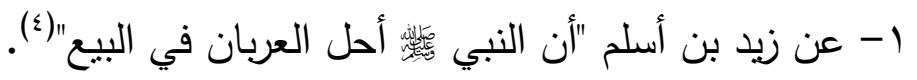

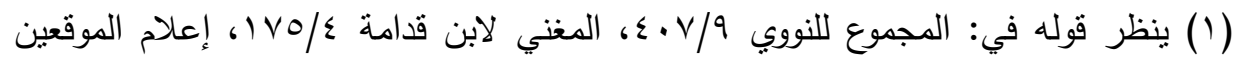

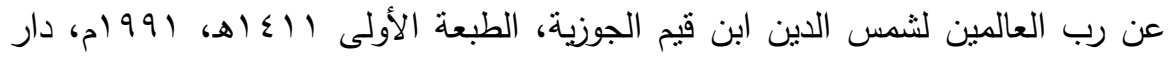

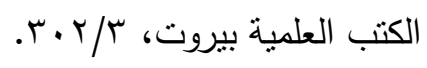

نافع بن عبد الحارث: نافع بن عبد الحارث بن حبالة الخزاعي، من أهل مكة، كان عامل

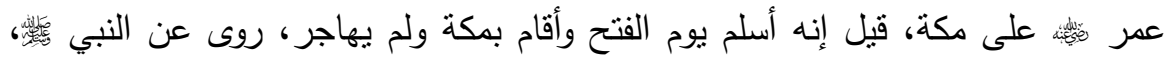

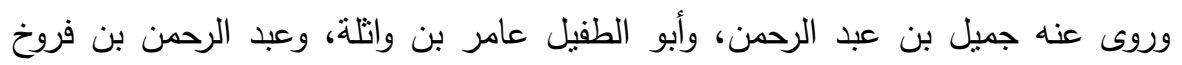

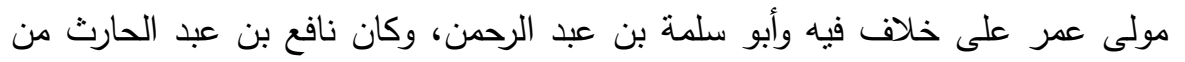

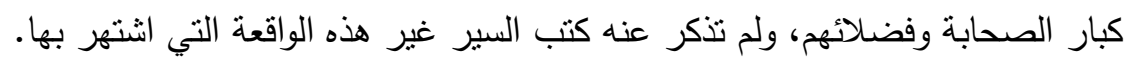

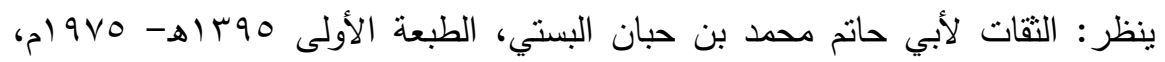

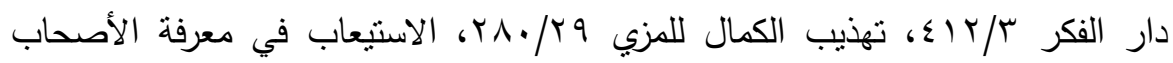

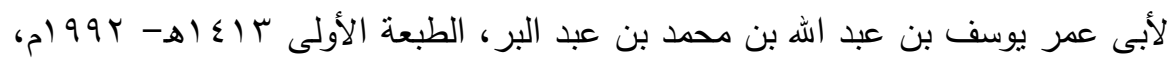

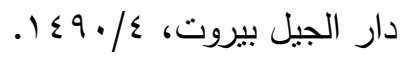

(r) زيد بن أسلم: أبو أسامة زيد بن أسلم، كان أبوه مولى عمر بن الخطاب، كان عالما عاملا

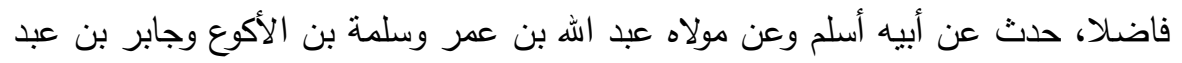

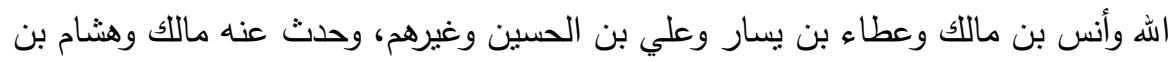

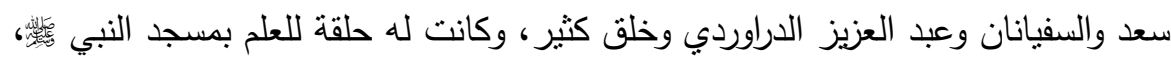
وتوفي سنة بسا (هـ. ينظر : حلية الأولياء وطبقات الأصفياء لأبى نعيم أحمد بن عبد اله الأصبهاني، الطبعة

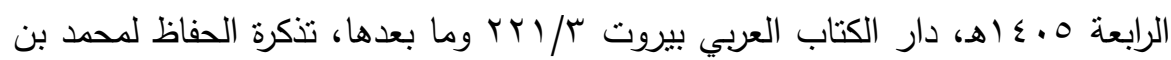

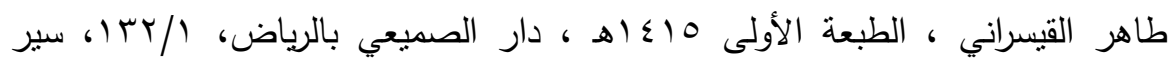

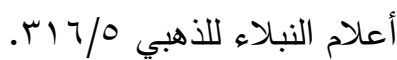

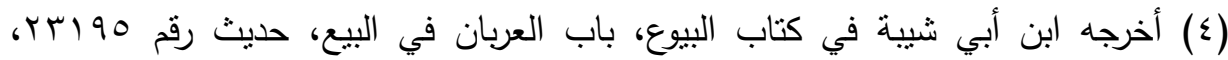

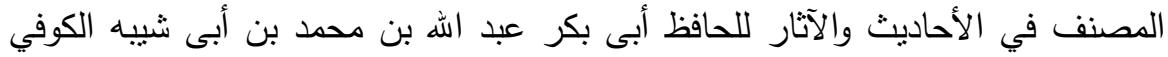

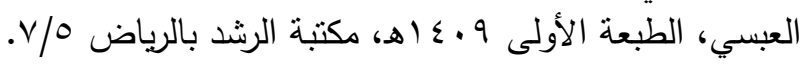




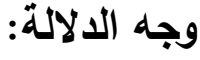

أن النبي ؤبه أحل بيع العربان، فكان الحديث صريح الدلالة على المشروعية

لهذا البيع مطلقا.

r- عن عبد الرحمن بـن فـروخ'() "أن نـافع بـن عبد الحسارث اثشترى دارا

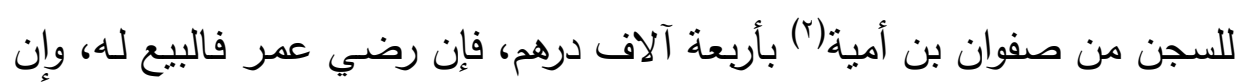

عمر لم يرض فأربعمائة لصفوان"(").

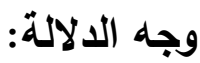

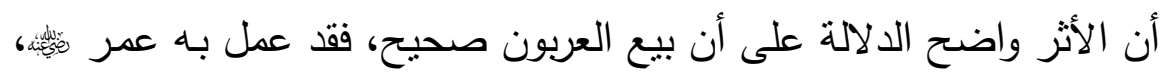

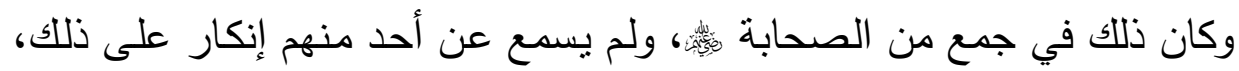
فكان دليلا على حل هذا البيع.

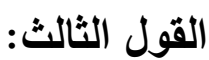

ذهب الحنابلة في وجها() إلى أن بيع العربون صحيح إذا قيده المتعاقدان بزمن معين، كإلى شهر من الآن، أو ما شابه ذلك.

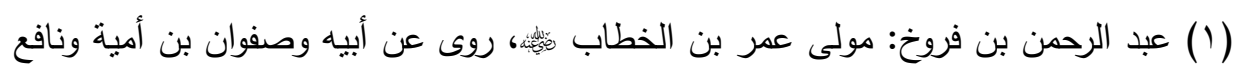

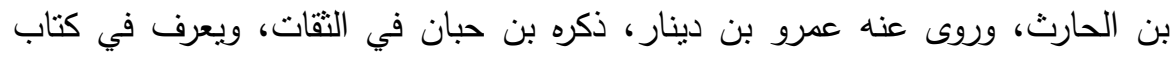

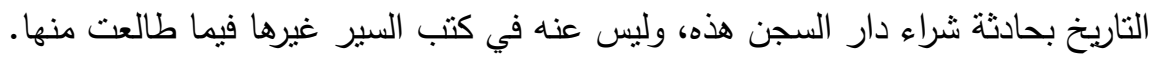

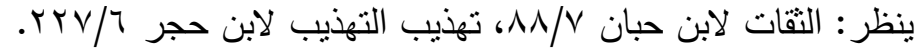

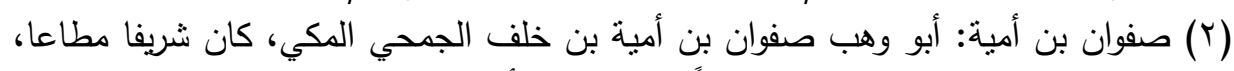

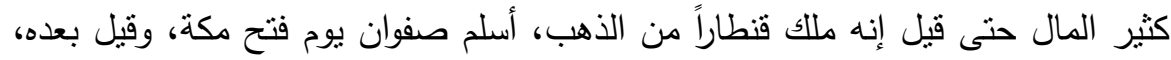

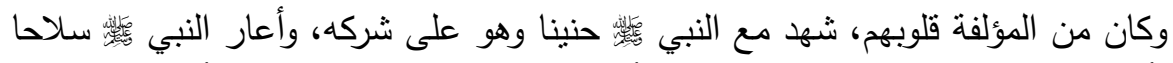

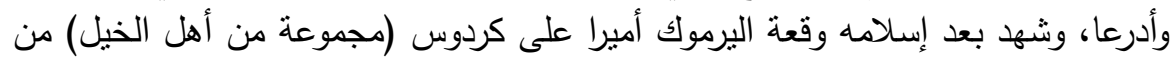

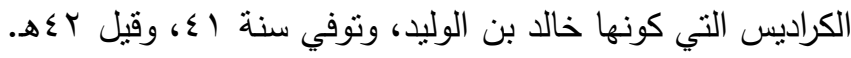

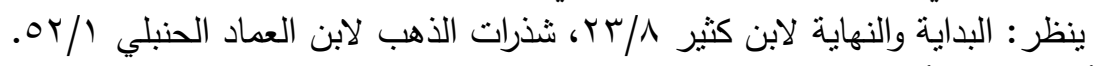

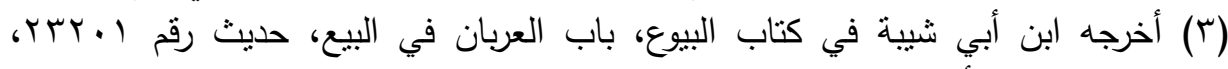

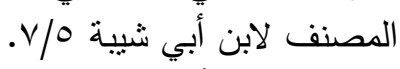

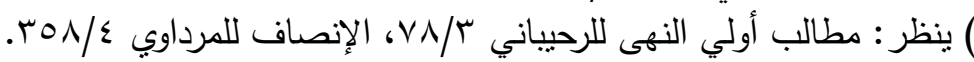




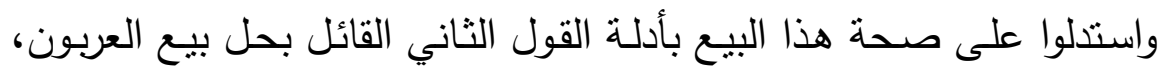

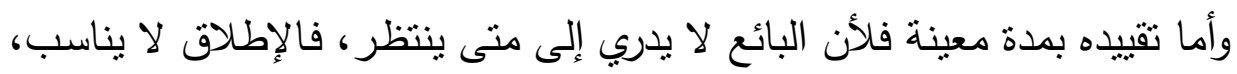
لما بلزم عليه من طول الأمد بلا نهاية، فيتزتب عليه من النزاع ما فيه كفاية (1).

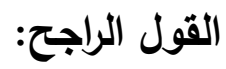
بعد ذكر الأقوال السابقة وأدلتهـا أرى أن القول الثالث القائـل بـأن البيـع

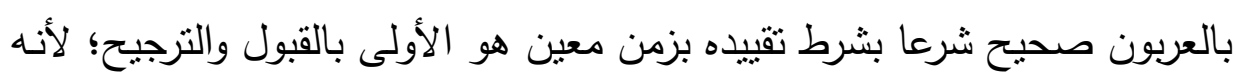

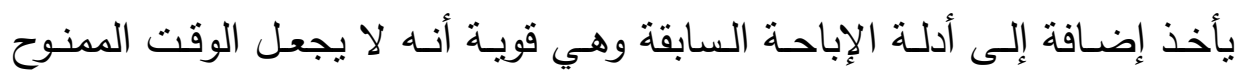

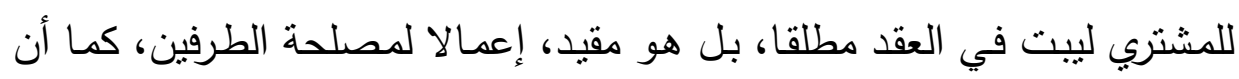
هذا التقييد دفع لما يحتمل وقوع من فساد وتتازع بسبب جهالة المدة.

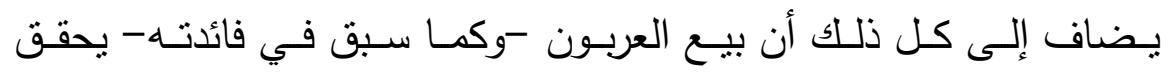

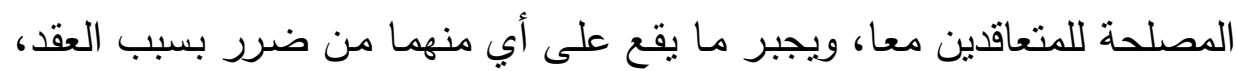
والهه أعلم.

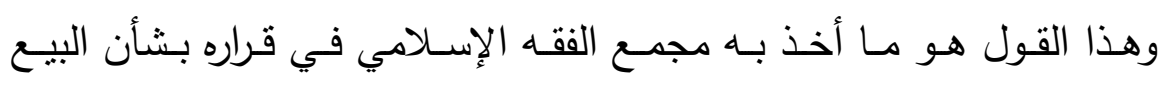
بالعربون، وهو ما أبينه تفصيلا بذكر القرار في المطلب التالي بإذن اله تعالى. 
=

\section{المطلب الرابع}

\section{فتوى مجمع الفقه الإسلامي بشأن بيع العريون}

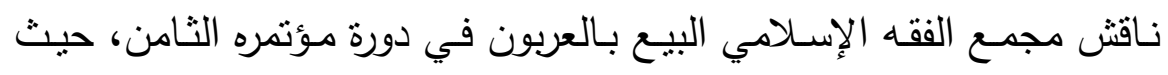

$$
\begin{aligned}
& \text { جاء فيه ما يلي: }
\end{aligned}
$$

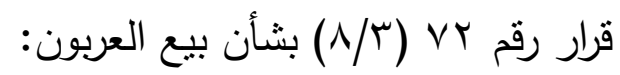

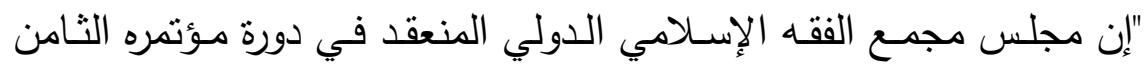

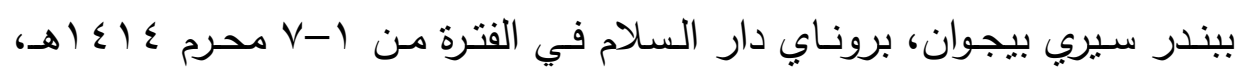

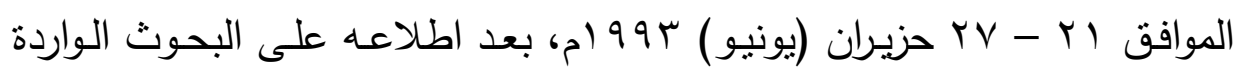

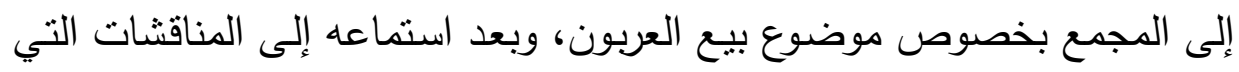

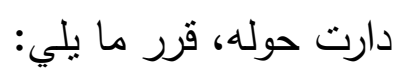

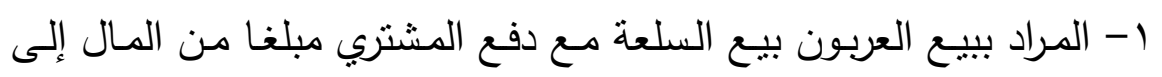
البائع على أنه إن أخذ السلعة احتسب المبلغ من الثمن، وإن تركها فالمبلغ للبائع.

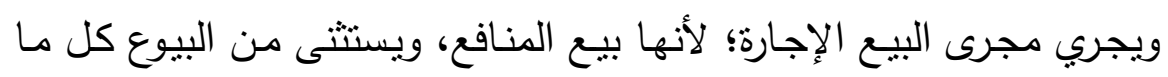

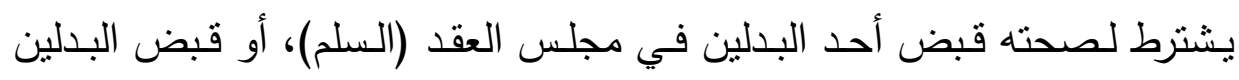

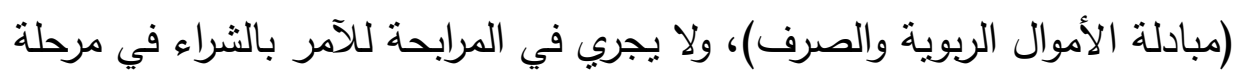
المواعدة، ولكن يجري في مرحلة البيع التالية للمواعدة.

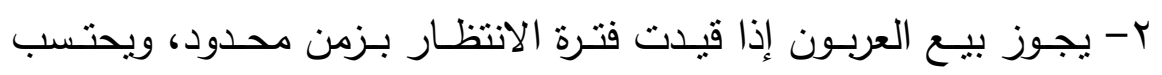

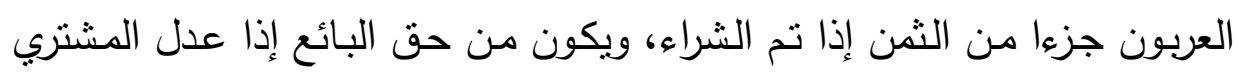

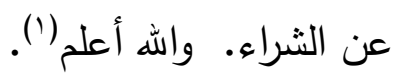

(1) مجلة مجمع الفقه الإسلامي، العدد الثامن /151/7. 


\section{الأصل الأي اعتمد عليه المجمع في فتواه بشأن بيع العريون}

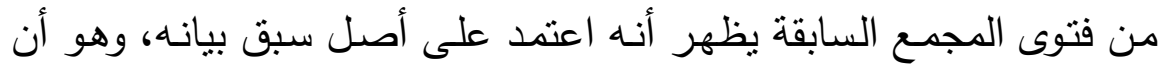
الأصل في الشروط والعقود الإباحة حتى يرد دليل الحظر ، وهي قاعدة خلافية الثية بيانها بتفصيل مناسب فيما يلي: حيث اختلف الفقهاء في هذه القاعدة على قولين:

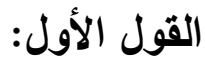

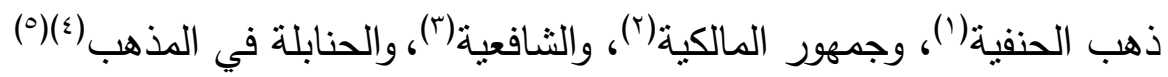
( (1) ينظر : المبسوط لثمس الدين محمد بن أحمد بن أبى سهل السرخسي، طبعة دار المعرفة،

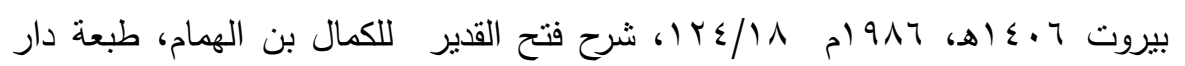

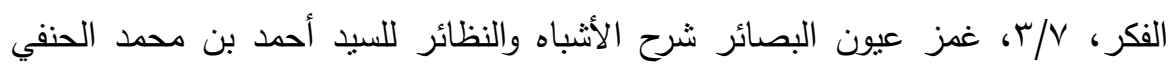

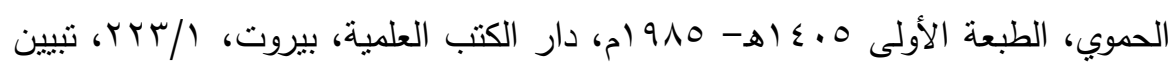

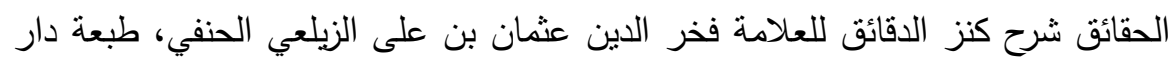

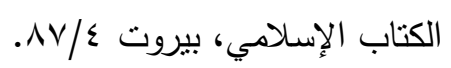

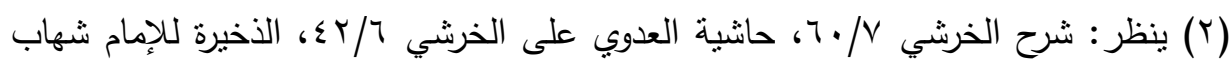

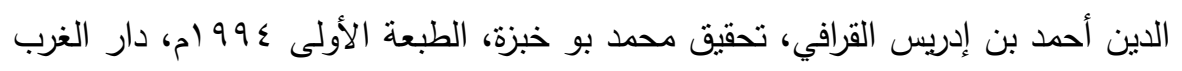

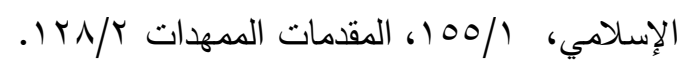

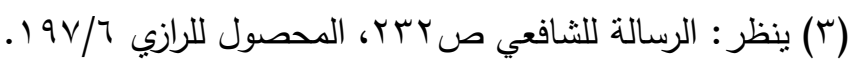

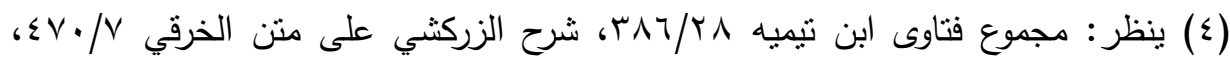

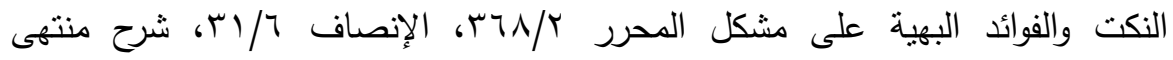

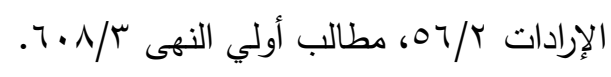

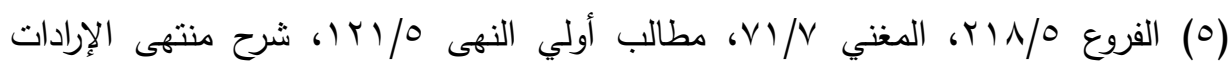

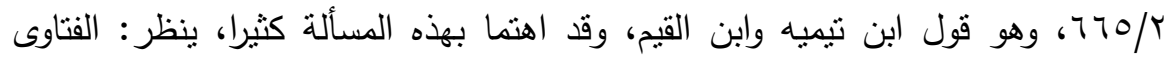

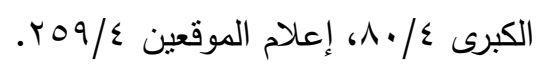


وشـريح(') والشعبي () إلى أن الأصل في العقود والمعاملات الإباحـة، ولا يحرم منها إلا ما ورد الثرع بتحريمه، أو دل على تحريمه وإبطاله نص أو قياس. واستدلوا على ذلك بالكتاب والسنة والمعقول:

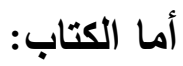

1- آيات عديدة تأمر بالوفاء بالعقود والعهود جملة ما لم تكن مخالفة لكتاب

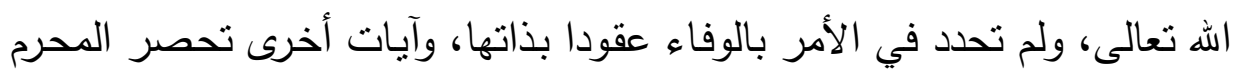
من العقود والأثياء، ويظهر منها أن ما عداها على الإباحة. فأما الآيات التي تأمر بالوفاء بالعقود والعهود عامة فمن ذلانك:

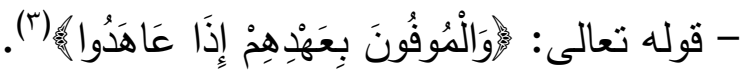

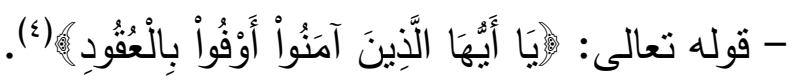

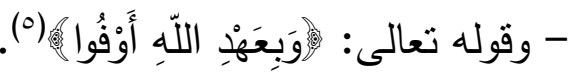

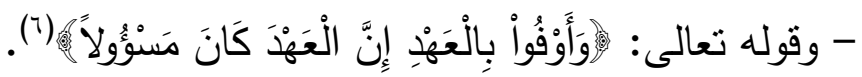

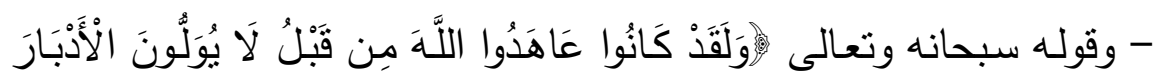

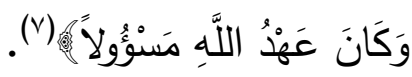

( (1) وورد عنه في ذلك قوله "لكل مسلم شرطه"، وقوله "الكسلمون عند شروطهم ما لم يُعْصَّ

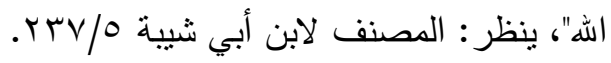

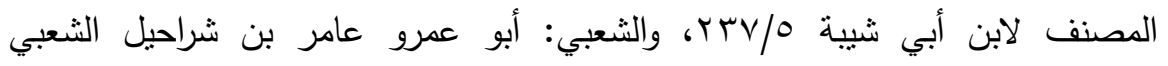

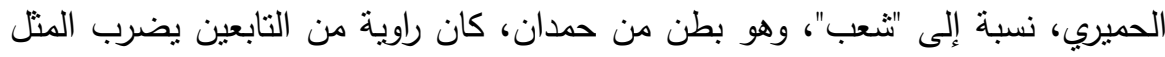

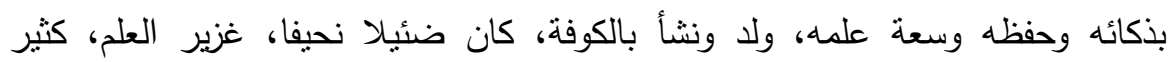

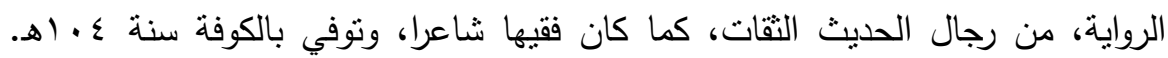

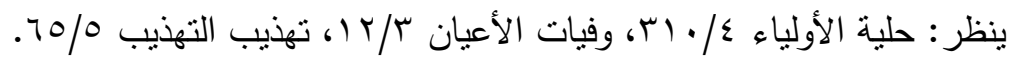

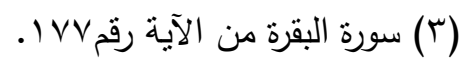

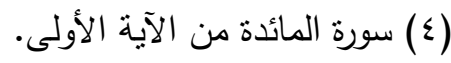

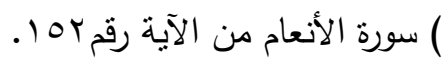

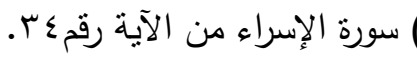

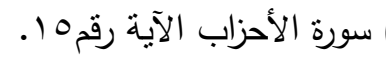




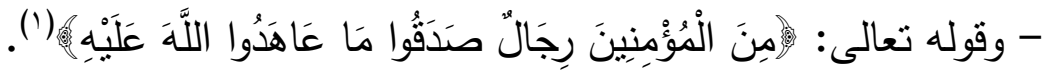

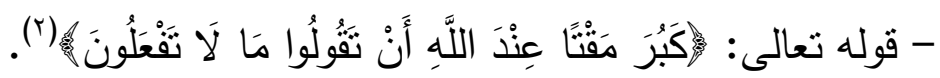
وجه الالالة: - 20

فقد أمر الله سبحانه- في هذه الآيات بالوفاء بالعقود، وهذا عام يشمل كل عقد، وكذلك أمرنـا بالوفـاء بـالعهود، فدخل في ذلك كل مـا عقده المـرء على نفسه(")، فدل على أن كل عقد يعقده المره على نفسه يكون صحيحا حتى يرد دليل الحظر، فتكون العقود الحديثة صحيحة شرعا حتى يرد ما يدل على حظرها من نص أو قياس. وأما الآيات التي تدل على حصر المحرمات، فمن ذلك:

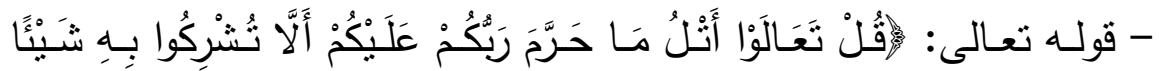

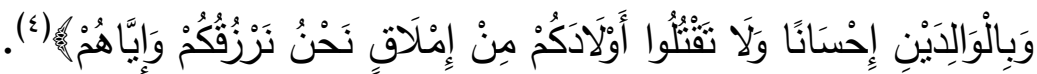
- وقوله تتعالى :

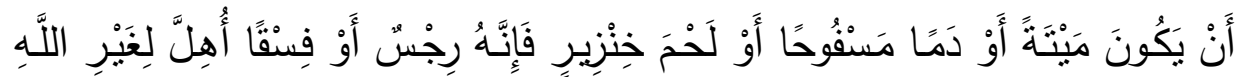
(0)

\section{وجه الالالة:}

فهاتـان الآيتان تـلان على أن المحرم وارد في القرآن والسنة نـصا، وأنـه

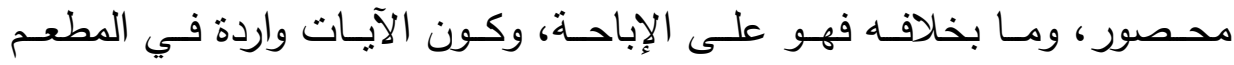

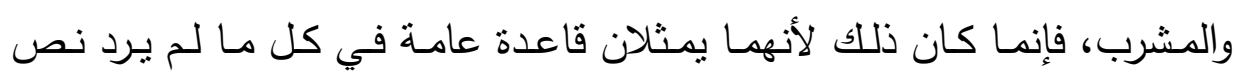
بتحريمه، حيث يبقى على أصل الحل إلى أن يرد دليل التحريم.

$$
\begin{aligned}
& \text { (1) سورة الأحزاب من الآية رقمب؟. } \\
& \text { (Y) سورة الصف الآية رقم ك. }
\end{aligned}
$$

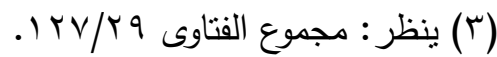

$$
\begin{aligned}
& \text { () سورة الأنعام من الآية رقم } 101 .
\end{aligned}
$$

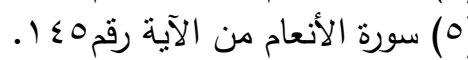




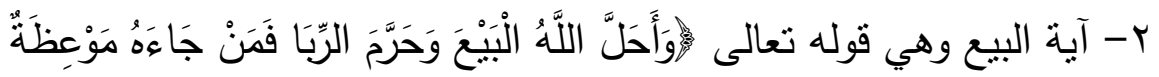

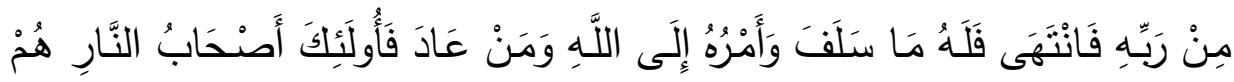

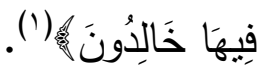

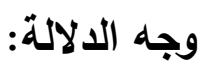

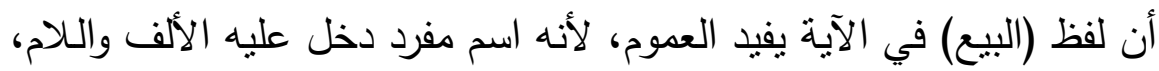

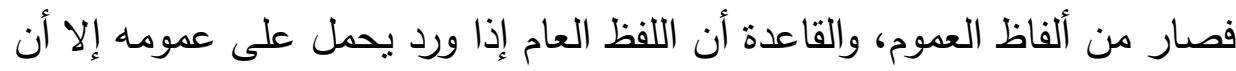

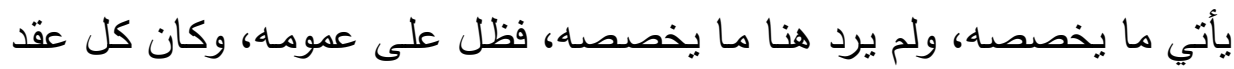

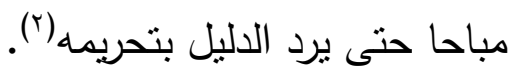

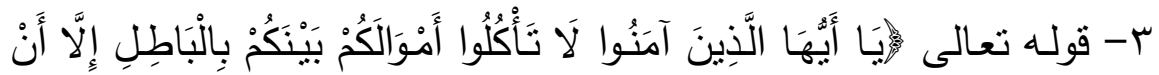

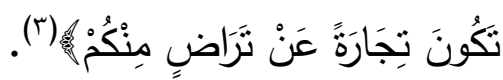
وجه الدلالة:

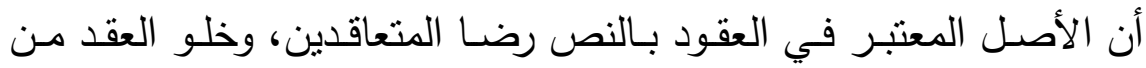

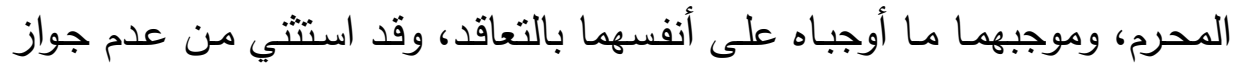

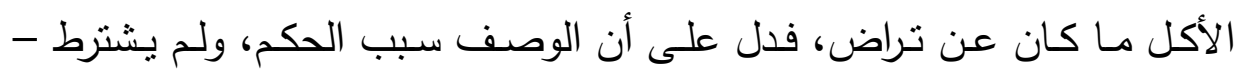

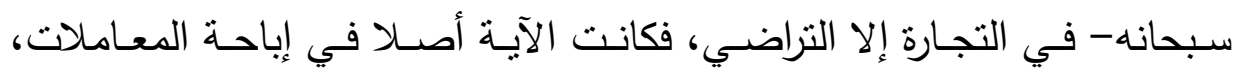

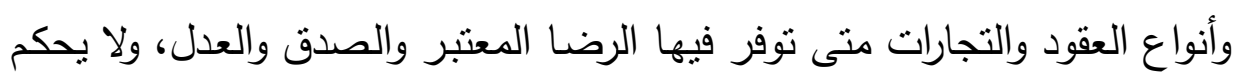
بالتحريم إلا بدليل معتبر شرعا.

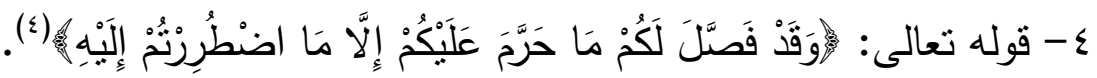

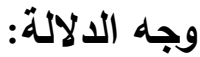

أن الآية تدل على أن اله -تعالى - فصل المحرمات، فما عداها مما لم يرد به تفصيل لا يكون محرما، وهذا ينسحب على العقود. 


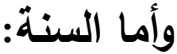

\section{فأحاديث:}

1 - الأحاديث التي تذل على حرمة نقض العقود وعدم الوفاء بها، ومن ذلك: - ما رواه ابن عمر كرضي الله عنهما- قال: قال رسول الله الله الأولين والآخرين يوم القيامـة يرفع لكل غادر لواء، فقيل هذه غدرة فلان بن

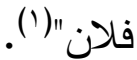

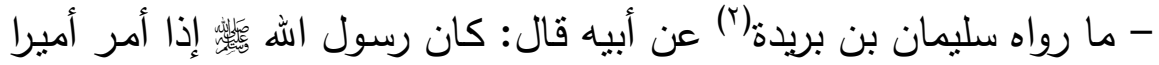
على جيش أو سرية أوصاه في خاصته بتقوى الله ومن معه من المسلمين خيرا، ثم قال: "اغزوا باسم الله، في سبيل الله، قاتلوا من كفر بالله، اغزوا، ولا تغلوا، ولا تغدروا، ولا تمثلوا، ولا تقتلوا وليدا .... الحديث" (َ).

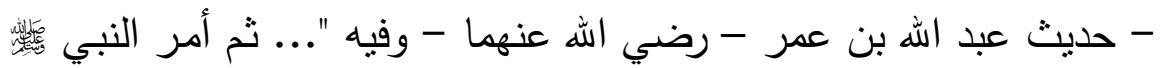
بـلالا أن يدفع إليه اللواء، فحمد الله، وصلى على النبي ئس ثم قال : "خذ يـا ابن عوف، فاغزوا جميعا في سبيل الله، فقاتلوا من كفر باله، لا تغلوا، ولا تغدروا، ولا

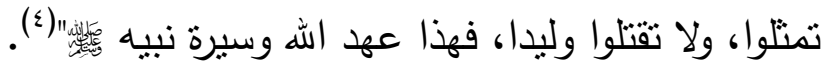

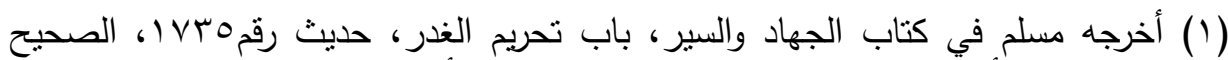

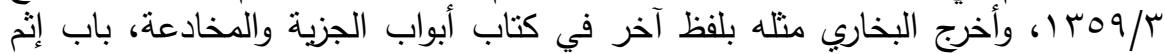

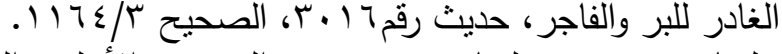

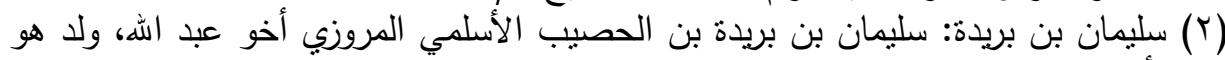

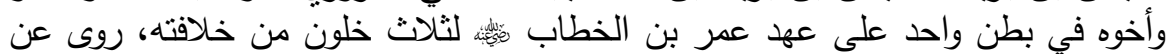

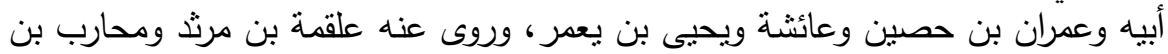

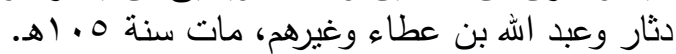

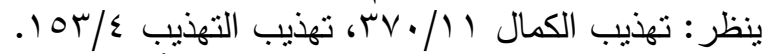

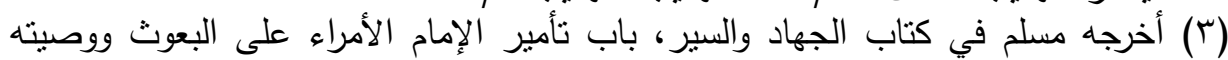

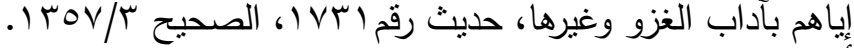

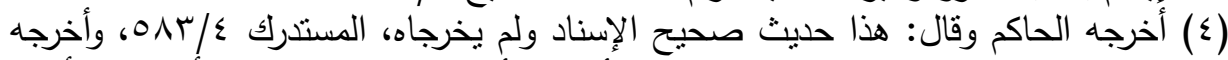

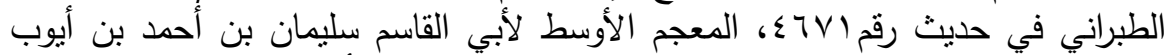

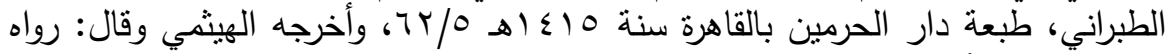

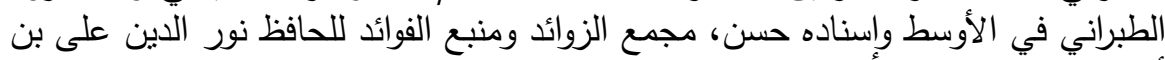

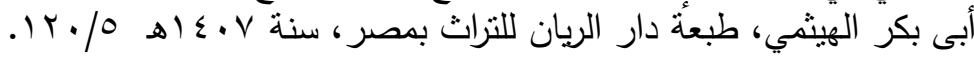




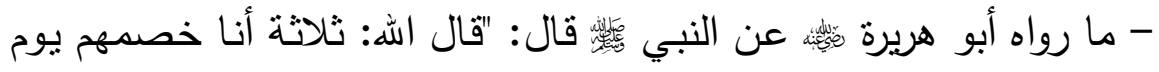
القيامة، رجل أعطى بي ثم غدر، ورجل باع حرا فأكل ثمنه، ورجل استأجر أجيرا

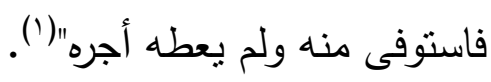

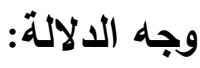

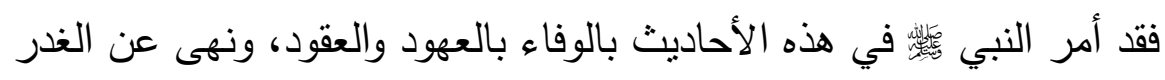

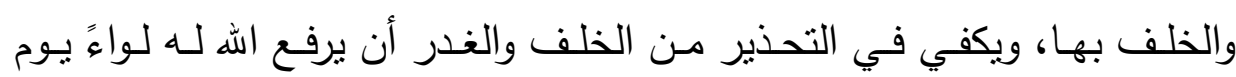
القيامة، والوفاء هنا كان عاما في كل عقد أو عهد لم يخالف شرع الله سبحانه-

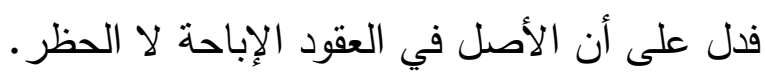

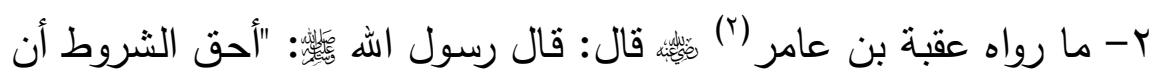
توفوا به ما استحللتم به الفروج"(").

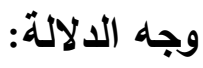

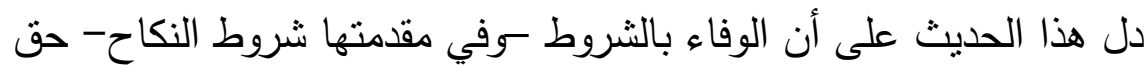

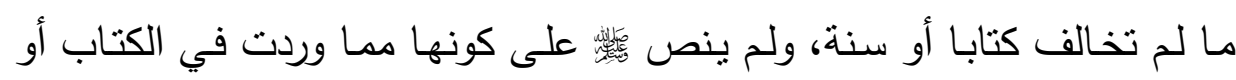

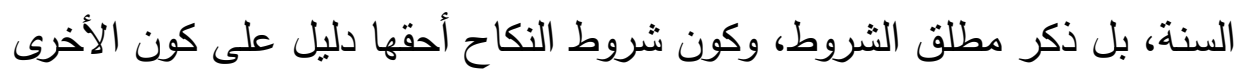
حق، ولكن النكاح أكثرها، لما فيه من حرمة وإفضاء بين الزورن تُورطين.

(1) أخرجه البخاري في كتاب البيوع، باب إثم من باع حرا، حديث رقمعالآ، الصحيح $. \vee V T / r$

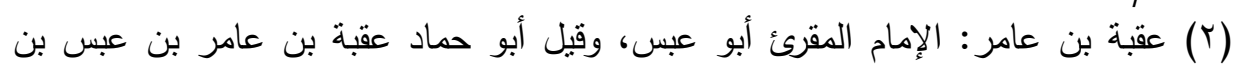

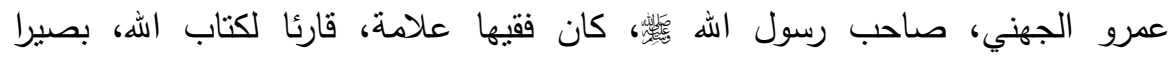

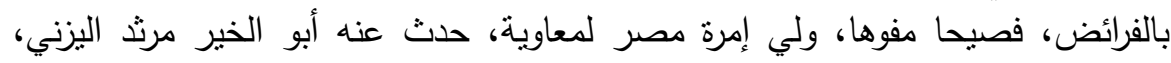

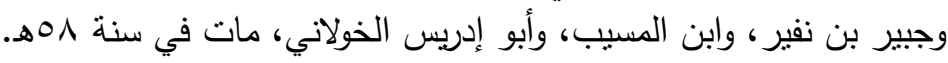

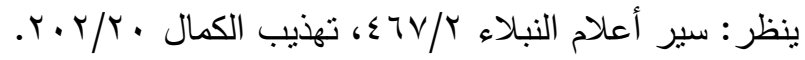

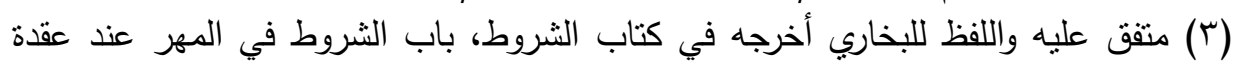

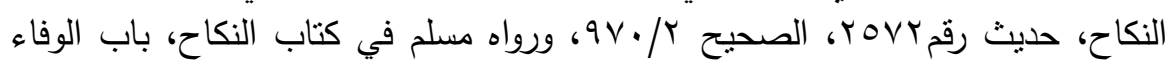

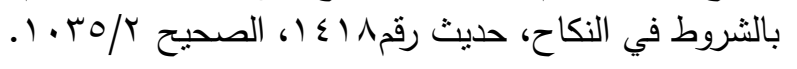


ب- مـا رواه كثير بـن عبد الله المزني عن أبيـه عن جده أن رسول الله قال: "الصلح جائز بين المسلمين إلا صلحا حرم حلالا أو أحل حراما، والمسلمون على شروطهم إلا شرطا حرم حلالا أو أحل حراما"(').

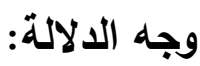

فهذا الحديث قد دل صراحة على أن الصلح والثرط بين المسلمين جائز ما لم يحل حراما أو يحرم حلالا، والعقود والشروط التي يستحدثها المسلمون مما لا تخالف نصا من كتاب أو سنة من هذا القبيل، فكانت جائزة.

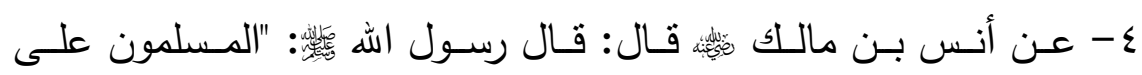
شروطهم ما وافق الحق من ذلك" (؟).

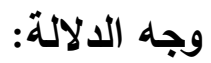

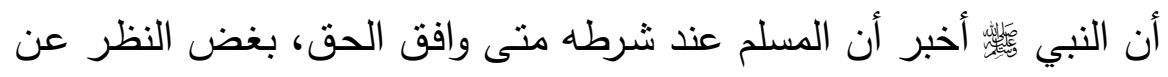
كون الشرط أو العقد منصوصا عليه، أم كان عقدا وشرطا مستحدثا بشرط ألا يخالف الكتاب أو السنة.

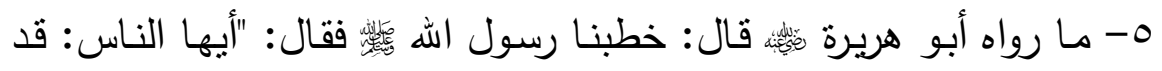

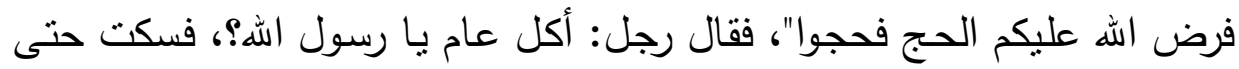

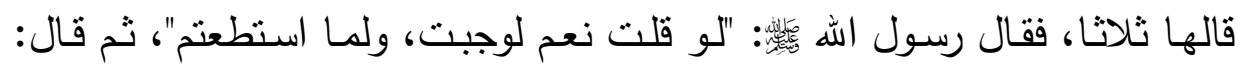

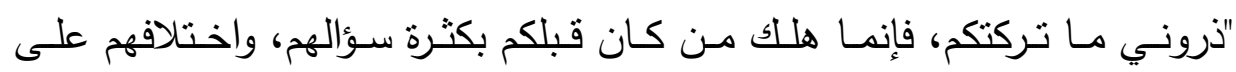

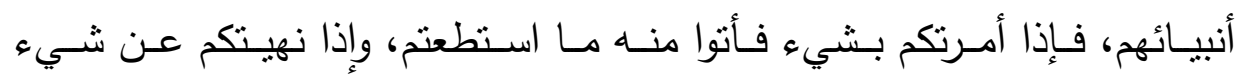

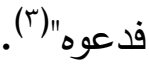

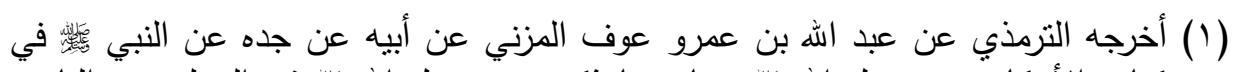

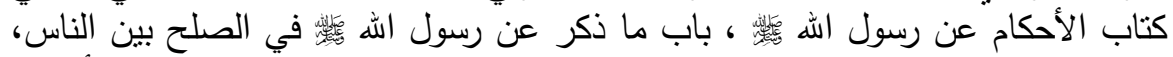

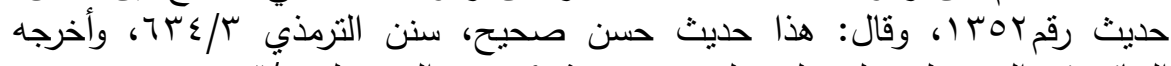

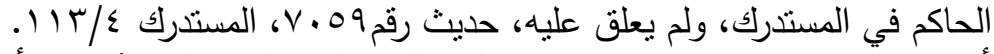

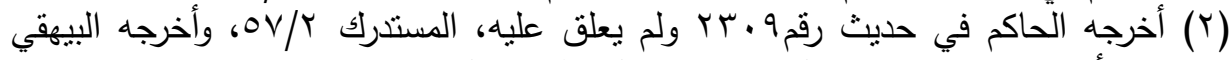

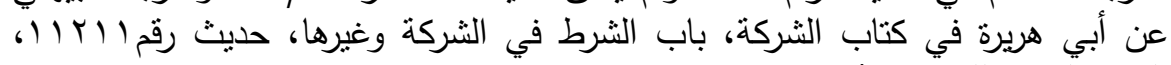

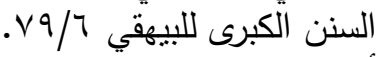

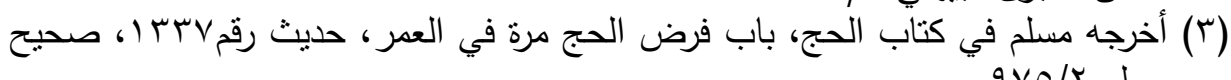
مسلم 


\section{(بيع العزبون}

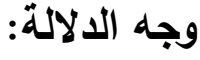

ففي هذا الحديث بين النبي ولئه أن ما كان واجبا أو حراما فقد بينه، وما تركه فأصله على الإباحة حتى يأتي البيان، فيدخل في ذللك العقود المستحدثة، فتكون

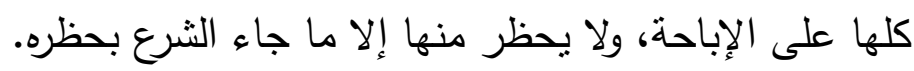

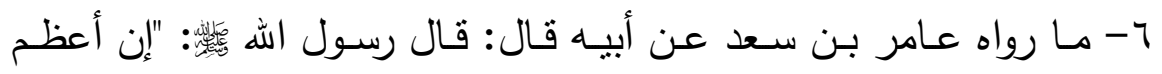
المسلمين في المسلمين جرما من سأل عن شيء لم يحرم على المسلمين فحرم

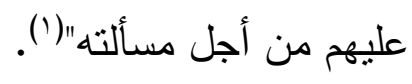

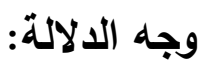

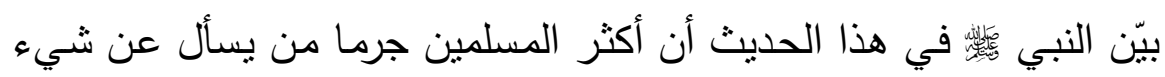

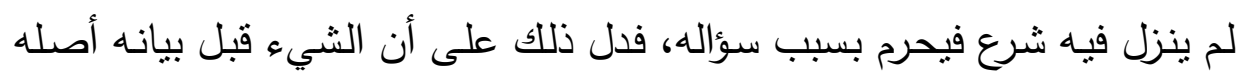

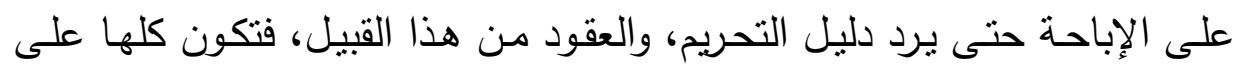
الصحة والجواز حتى برد دليل الحظر. وأما المعقول:

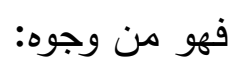

الأول: أن العقود والشروط مـن بـاب الأفعـال العاديـة، والأصلـ فيهـا عدم

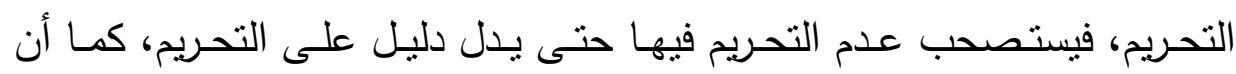

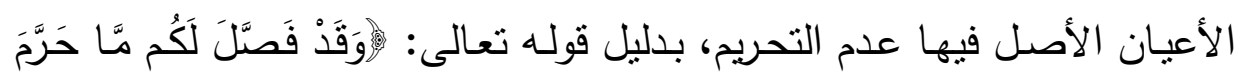

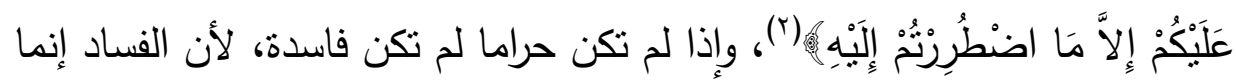

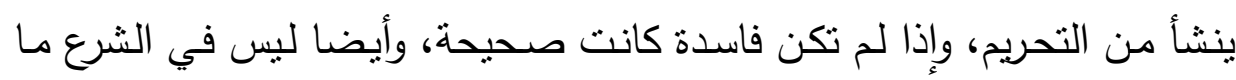

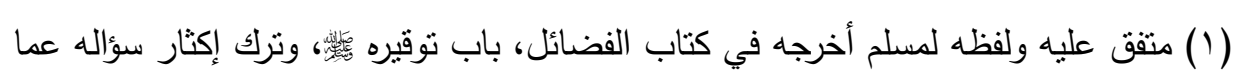

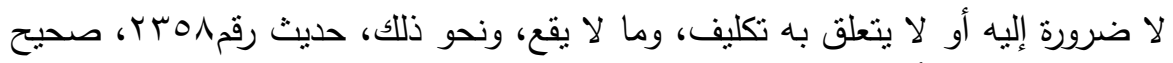

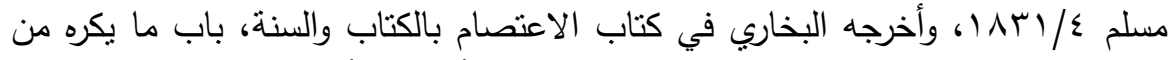

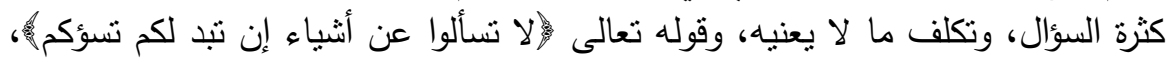

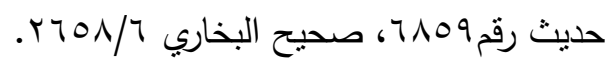

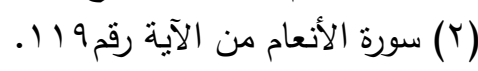


يدل على جنس العقود والثروط إلا ما ثبت حله بعينه، وانتفاء دليل التحريم دليل على عـدم التحريم، فـإذا حرمنـا العقود والـشروط التـي تجـري بـين النـاس في معاملاتهم العادية بغير دليل شرعي كنا محرمين ما لم يحرمه الله، بخلاف العقود التي تتضمن شرع ما لم يأذن به الله، فتلك حرام بلا نزاع|'(أ). الثاني: أن الآيـات والأحاديث تحض على الوفاء بالعهد، وإذا كان حسن الوفاء ورعاية العهد مأمورا به علم أن الأصل صحة العقود والشروط، إذ لا معنى للتصحيح إلا مـا ترتب عليه أثره وحصل بـه مقصوده، ومقصوده هو الوفاء بـه، وإذا كان الثرع قد أمر بمقصود العهود والعقود دل على أن الأصل فيها الصحة

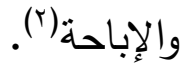

الثالث: أن الأصل في العقود رضا المتعاقدين، ونتيجتها هو ما أوجباه على

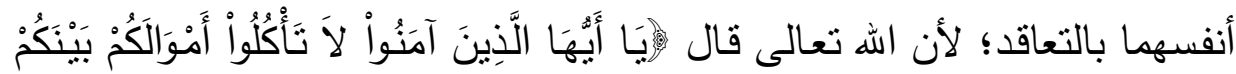

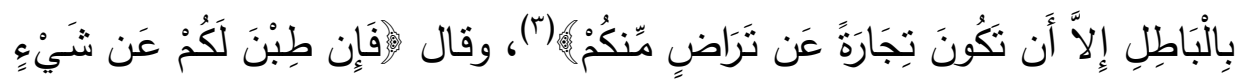

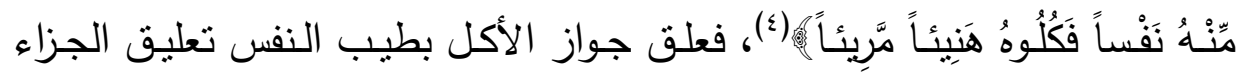
بشرطه، فدل على أنه سبب له، وهو حكم معلق على وصف مشتق مناسب، فدل على أن ذلك الوصف سبب الحكم، وكذللك لم يشترط في التجارة إلا التراضي، وذلك يقتضي أن التراضي هو المبيح للتجارة، وإذا كان الأمر كذلك فإن طابت نفس المتعاقدين كان العقد صحيحا إلا أن يتضمن ما حرمه الله ورسوله(0).

(1) بتصرف من: مجموع الفتاوى 9 / / 10، الموافقات في أصول الثريعة لأبي إسحاق إبراهيم

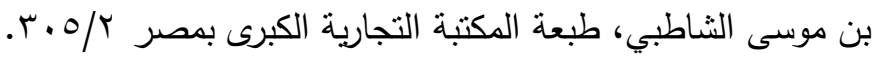

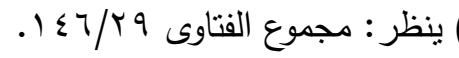

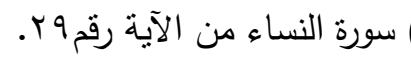

$$
\begin{aligned}
& \text { سورة النساء من الآية رقمء. }
\end{aligned}
$$

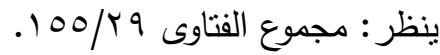




\section{بيع العريون}

الرابع: أنه ليس في الثرع ما يدل على تحريم جنس العقود إلا عقودا معينة، فانتفاء دليل التحريم دليل على عدمه، فتبت بالاستصحاب العقلي، وانتفاء الداليل

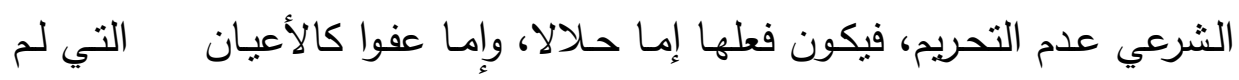

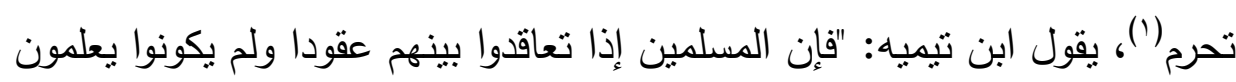

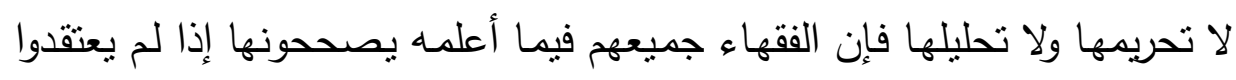

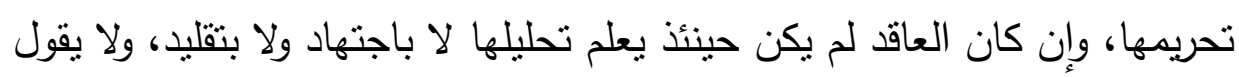

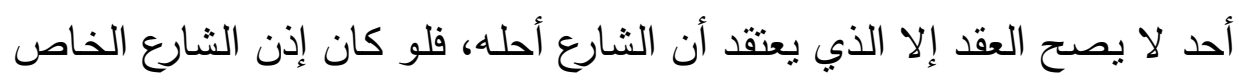
شرطا في صحة العقود لم يصح عقد إلا بعد ثبوت إذنه"(†).

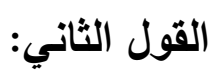

ذهب الإمام أحمد في رواية(†) والأبهري() من المالكية(ْ) إلى أن الأصل في

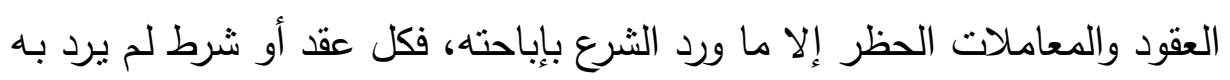
الثرع فلا اعنبار لله، وهو محظور حتى يرد الثرع بجوازه.

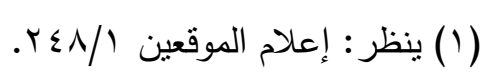

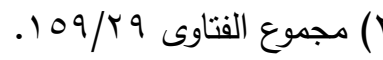

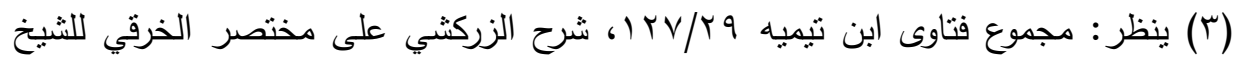

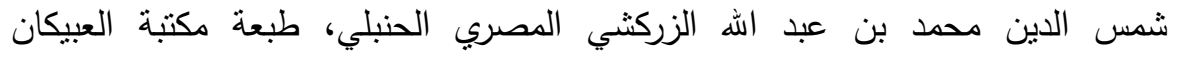

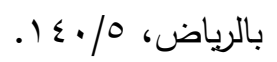

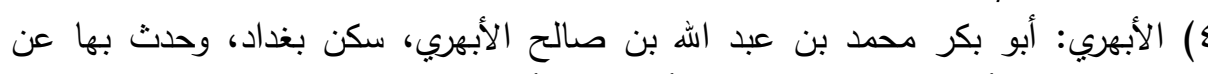

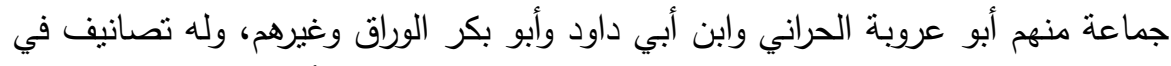

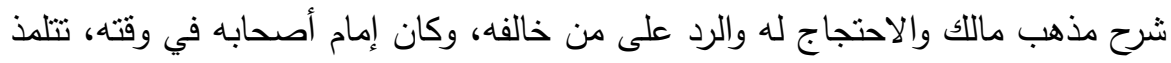

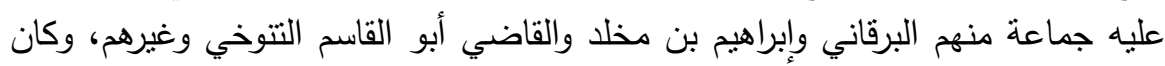

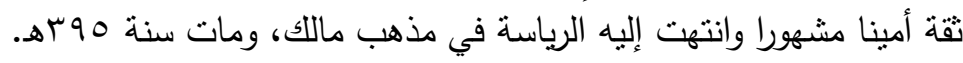

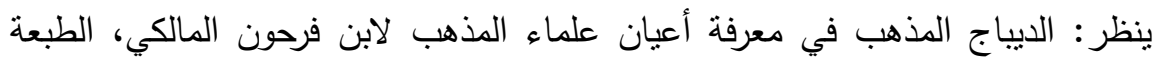

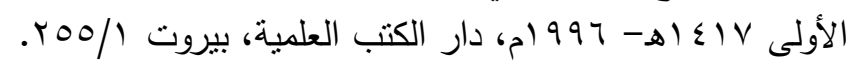

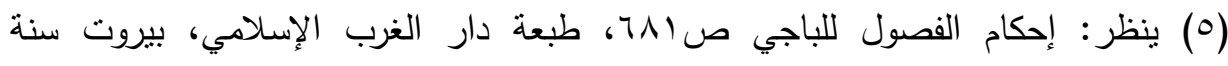


واستدلوا على ذللك بالكتاب والسنة والمعقول:

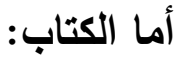

ا - قوله تعالى:

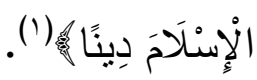

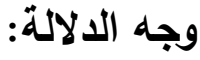

فقد أخبر الله -تعالى - أن الدين قد كمل، وجاء فيه البيان لكل جائز ومحرم،

ومن ذلك العقود، فكان الأصل في أي عقد أنه محظور حتى يرد دليل الإباحة.

ونوقش هذا:

بأن من كمال الشريعة وبديع نظامها أنها دلت على إباحة المعاملات التي

يحتاج إليها الناس في دنياهم، فالشريعة قد جاءت في بـاب المعاملات بالآداب

الحسنة، فحرمت منها ما فيه فساد، وأوجبت ما لابد منه،، وكرهت ما لا ينبغي، وندبت إلى ما فيه مصلحة راجحة، وما لم يرد في الثريعة تحريمه أو إباحته فهو

مسكوت عنه(r)

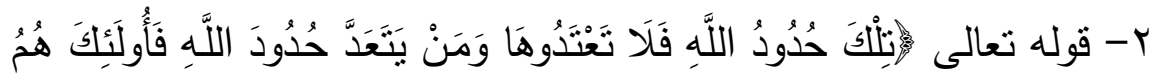

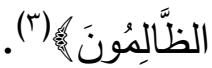

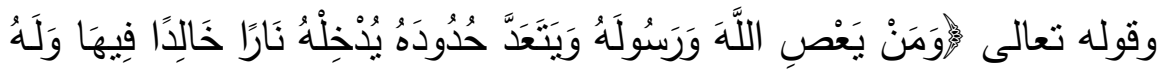

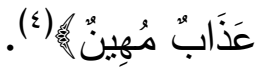

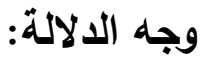

فقد وضع الله -تعالى - حدودا، وحذر من تعديها، وبيّن الحلال من الأثياء

والعقود، فكان كل عقد لم يرد بـه الشرع الأصل فيه أنه محظور حتى يرد دليل 
بأن تعدي حدود اله هو تحريم ما أحله اله، أو إباحة ما حرمه الله، لا إباحة

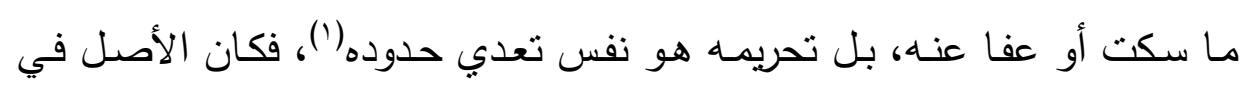
العقود الإباحة لا الحظر.

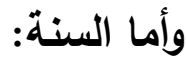

فأحاديث كثيرة تدل على عدم جواز الاثتراط إلا بما يكون موافقا للكتاب

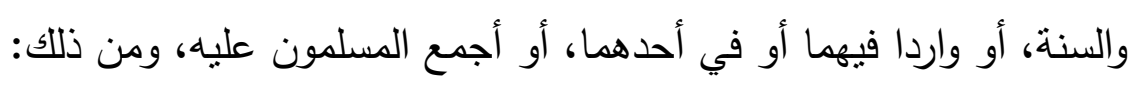

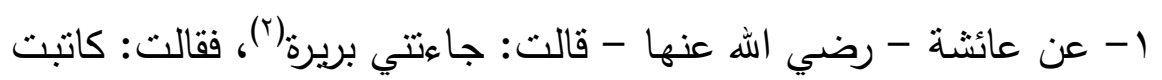

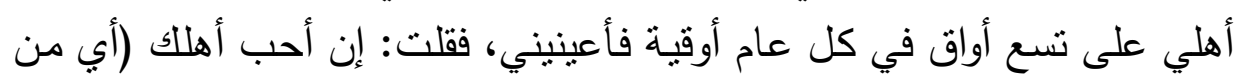

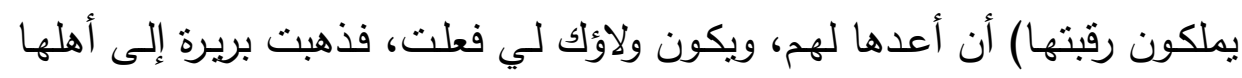

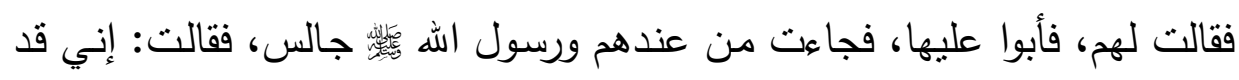

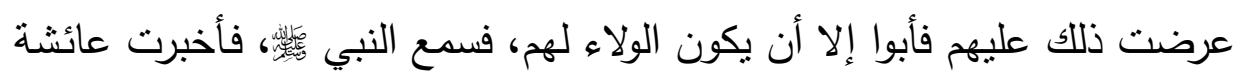

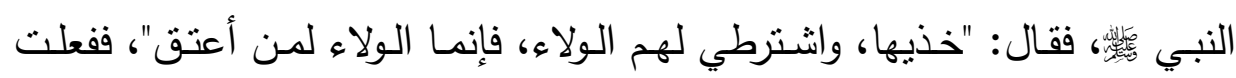

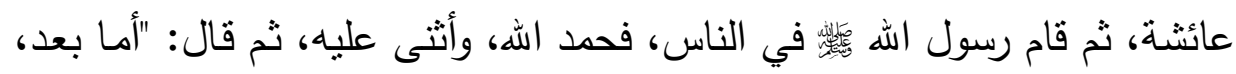

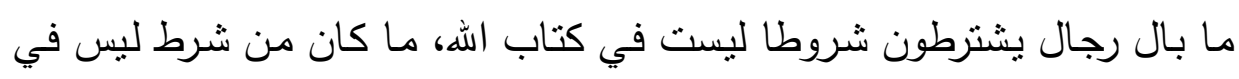

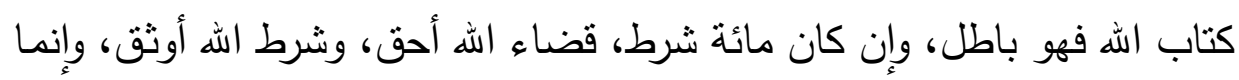

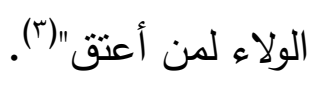

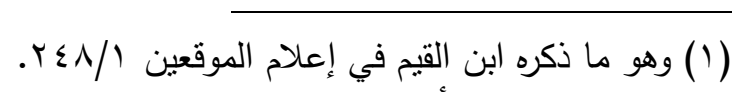

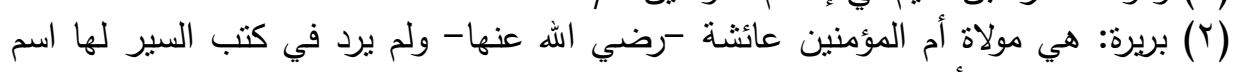

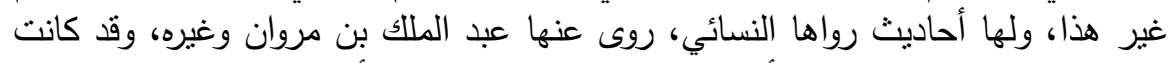

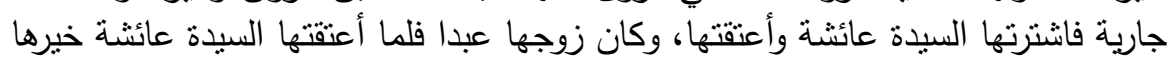

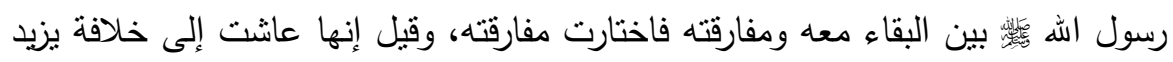

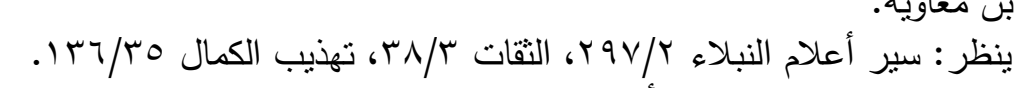

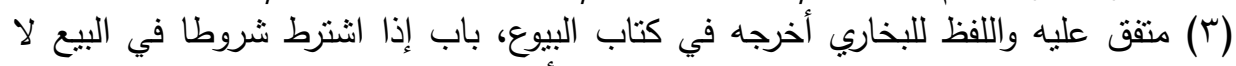

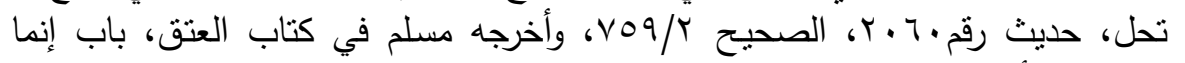

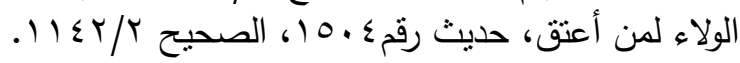

$$
\begin{aligned}
& -r \circ \varepsilon-
\end{aligned}
$$


د. محمد بليه حمد العجمي لحس

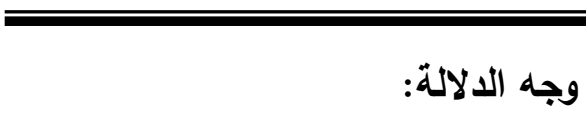

فقوله

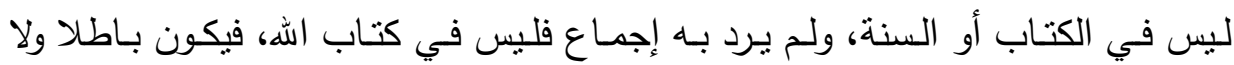

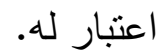

$$
\text { ون ثلاثش هذا: }
$$

الأول: أن المراد بقول النبي أسلّ: "ليس في كتاب الله"، أي: ما كان مخالفا لحكم الله

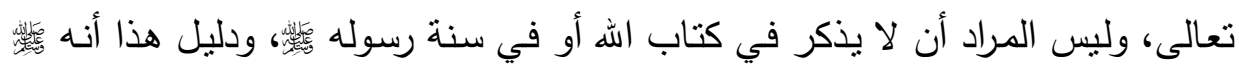

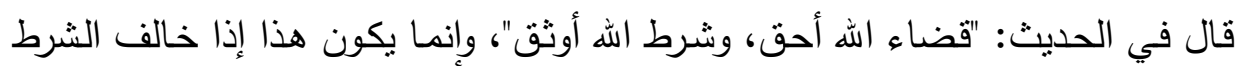

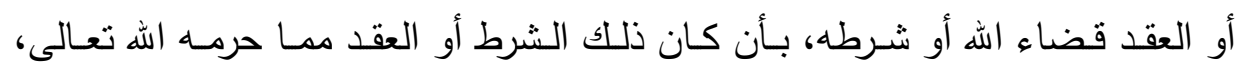
فضمون الحديث أن العقد أو الثرط إذا لم يكونا من الأفعال المباحة فإنه يكون محرما باطلا' (') (20)

الثاني: أن المراد من الحديث كل شرط ليس في حكم الله وشرعه(؟)، وليس المراد

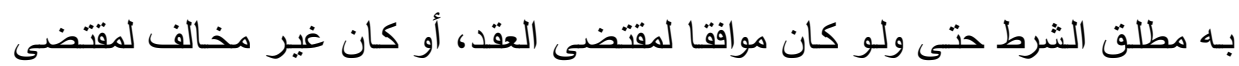

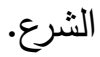

الثالث: على فرض التسليم بأن مراد النبي أبل منع كل عقد أو شرط لم يذكر في

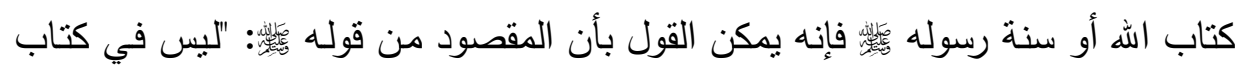

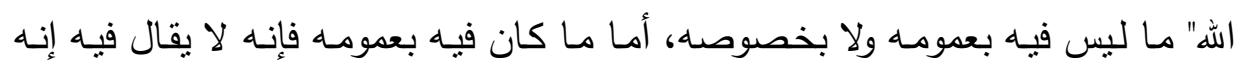

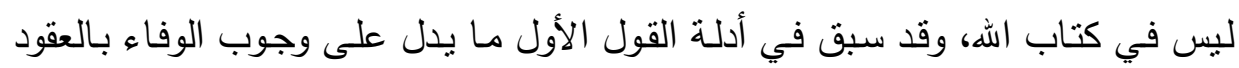

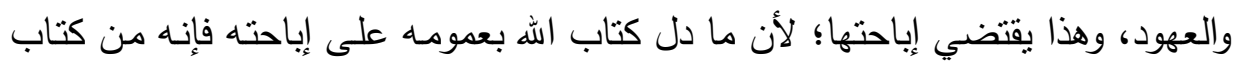
اله حتما، فكان الأصل في العقود الإباحة لا الحظر (־).

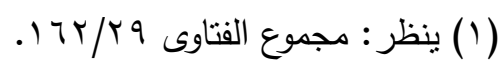

$$
\begin{aligned}
& \text { (r) (r) ينظر : مجموع الفنتاوى }
\end{aligned}
$$

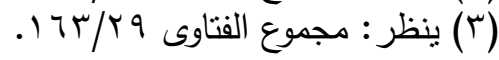

$$
\begin{aligned}
& -r 00-
\end{aligned}
$$




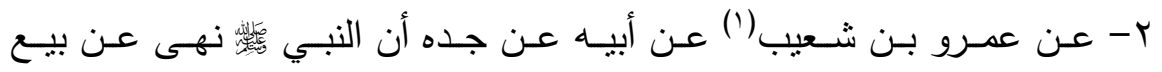

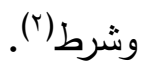

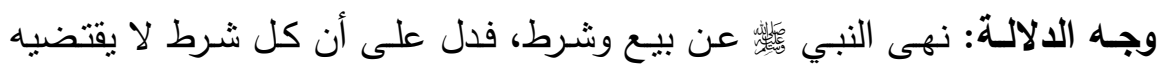

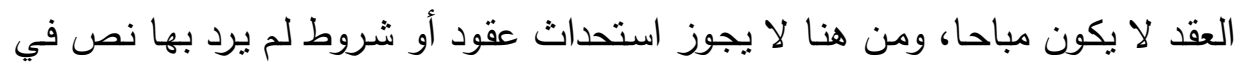

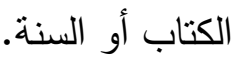

ويناقش هذا: بأن الحديث ليس صحيحا، فقد ضعفه كثير من أهل الحديث(")،

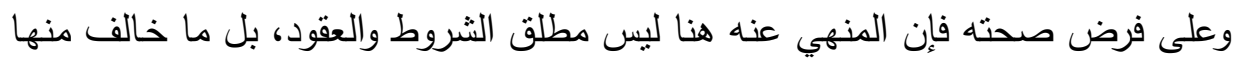

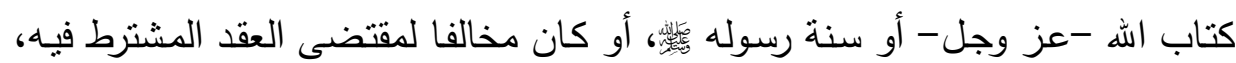
فكان خارجا عن محل النزاع.

r- عن عائشة كرضي اله عنها - قالت: قال رسول الله

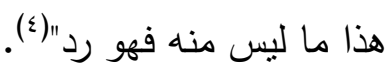

وجه اللالادة: أن الحديث صريح الدلالة في رد كل ما هو مستحدث مما لا أصل الصل

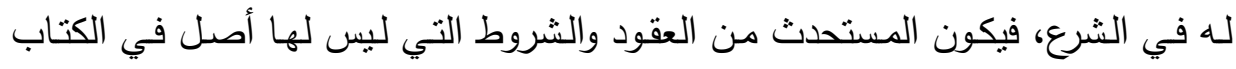

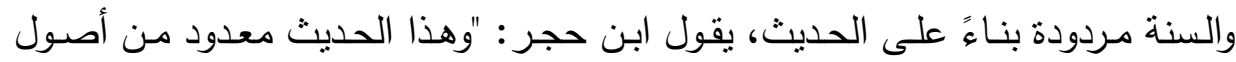

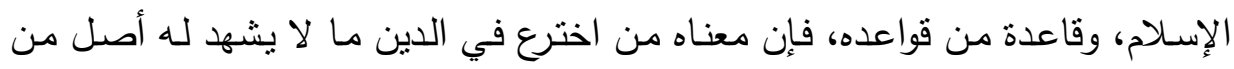

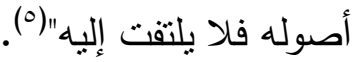

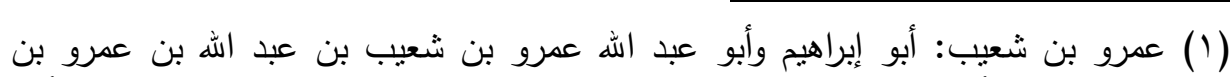

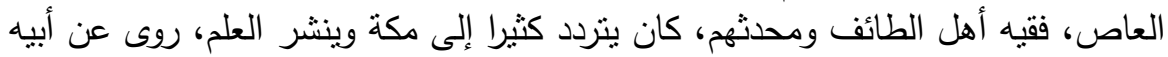

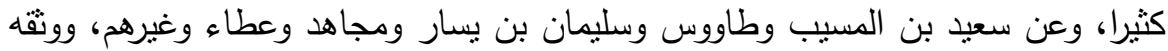

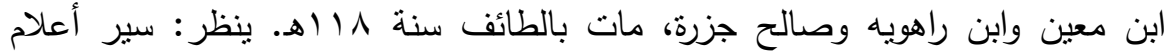

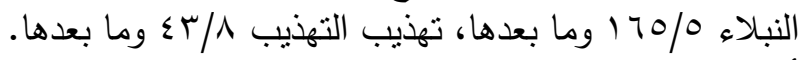

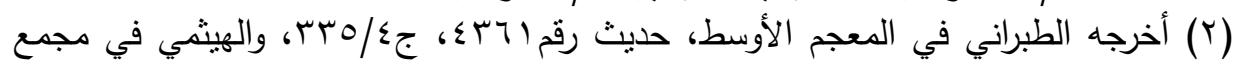

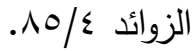

(r) ومن ذللك ما قاله الهيثمي: وفي طريق عبد الله بن عمرو مقال، ينظر: مجمع الزوائد $.10 / \varepsilon$

(ع) متفق عليه واللفظ لمسلم أخرجه في كتاب الأقضية، باب نقض الأحكام الباطلة ورد

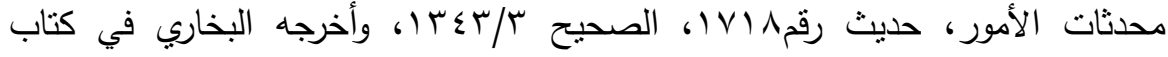

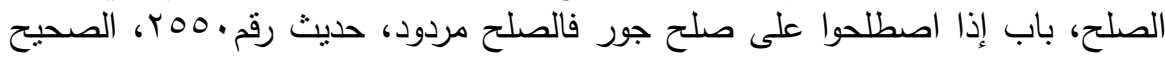


ويناقش هذا: بأن الحديث صحيح ومن قواعد الدين بالفعل كما ذكرتم ولكن المراد

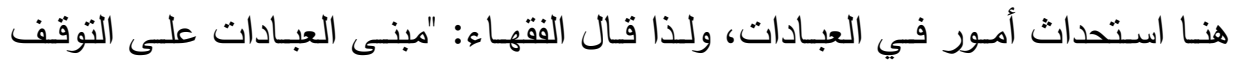
والاحتياط أو رعايـة الاتباع"(')، أمسا المعاملات فعلى العكس، إذ هي مما يتغير بتغير لئل الزمان والمكان والأشخاص، ولو أبطل كل جديد منها لكان في ذلك حجر على الناس، وتعطيـل لأمسور حيـاتهم، والـشريعة ميسرة لا معسرة، ومبناهـا على ذلـ خاصسة في

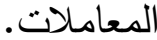

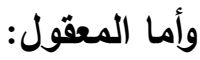

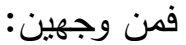

الأول: أن الشريعة شـاملة لكل شيء، وقد تكفلت ببيان مـا يحقق مصالح الأمـة، ومنها العقود، على أساس من العدل، وليس من العدل ترك الحريـة للناس في عقد ما يريدون من العقود، وإلا أدى ذلك إلى هدم نظام الثريعة (؟). ويناقش هذا: بأن الحرية في استحداث العقود ليس على إطلاقها، بل هو جارِ في إطار الثريعة وتحت مبادئها، فلا يجوز استحداث ما يخالفها، والحديث هنا عن العقود التي لا تخالف الثريعة، ولم يرد بها نص في الثرع. الثاني: قياس كل ما لم يرد به نص من العقود والشروط على شرط الولاء المذكور

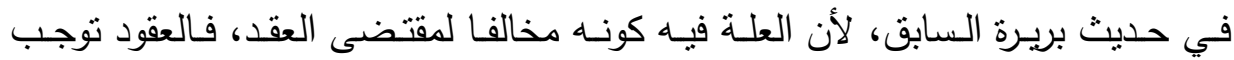
مقتضياتها بالثرع، فإرادة تغييرها تغيير لما أوجبه الشرع، فيكون بمنزلة تغيير العبادات، لهونه وحيث كان شرط الولاء باطلا فيكون كل ما شابهه من العقود والشروط التي لم ترد في الكتاب أو السنة باطلة)(r).

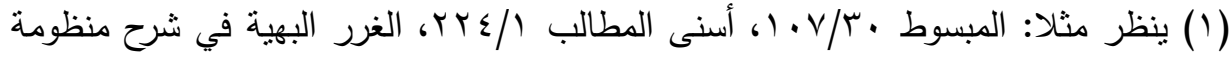

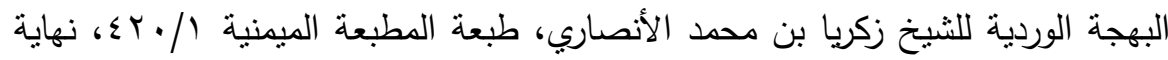




\section{=يع العربون}

ويناقش هذا: بأن القياس هنا غير صحيح، لكونه قياسا مع الفارق، ووجه الفرق

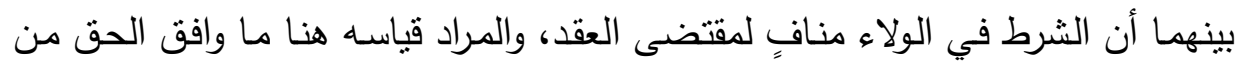

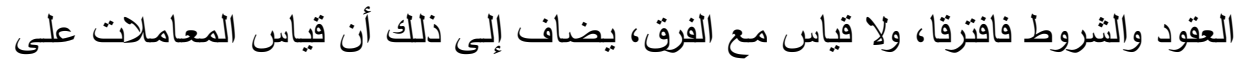

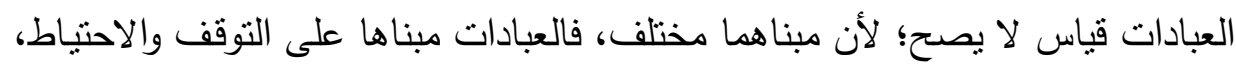

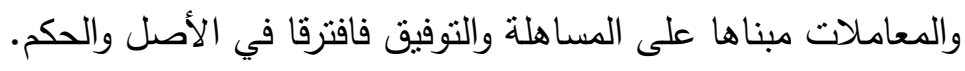

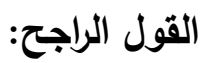

أرى أن القول الأول الذي يرى أن الأصل في العقود والشروط الإباحة حتى يرد

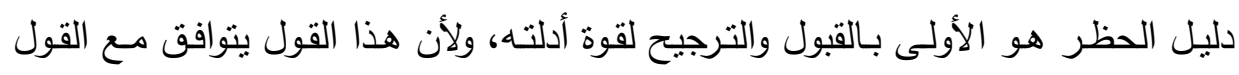

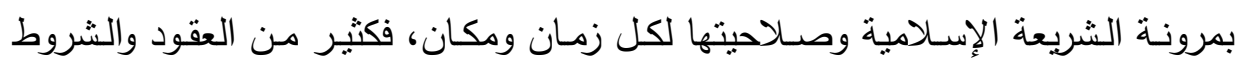

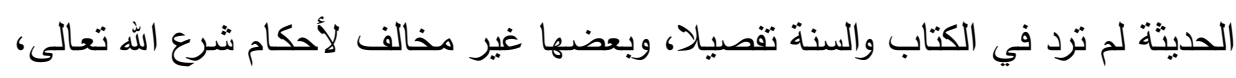

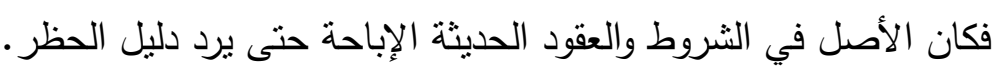

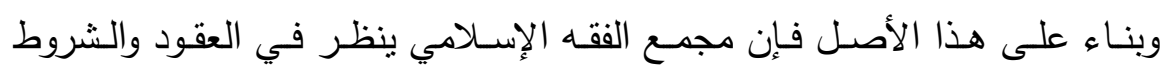

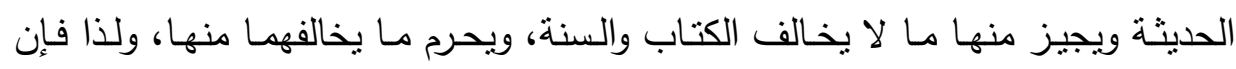

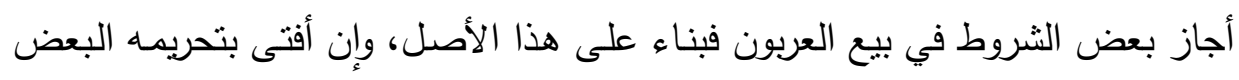
فإنما ذلك على اعتبار أنها تخالف أحكام القرآن والسنة على ما سبق ليق بيانه تفصيلا. 


\section{الخاتمـة}

ا - أن بيع العربون: هو العقد الذي يتفق فيه العاقدان على دفع مقدم يكون جزءا من بدله عند تمامه، ومفقودا عند العدول عنه .

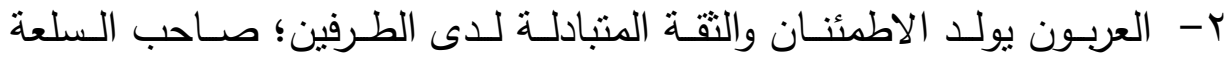

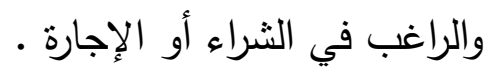

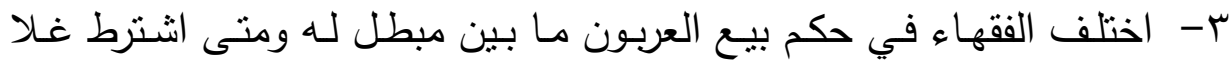
يصح البيع، ويرى آخرون أن البيع بالعربون صحيح وجائز شرعا، ولكل أدلة

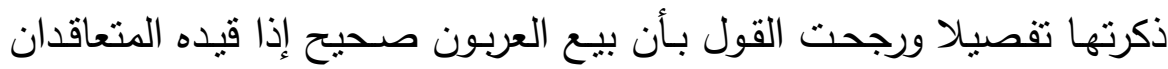

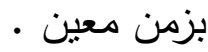

ع - بيع العربون يحقق المصلحة للمنعاقدين معاً، ويجبر ما يقع على أي منهما

$$
\text { من ضرر بسبب العقد. }
$$

ه- ناقش مجمع الفقه الاسـلامي موضوع البيع بالعربون وتوصل إلى أنه يجوز بيع العربون إذا قيدت فترة الانتظار بزمن محدود، ويحتسب العربون جزءا من الثمن إذا تم الثراء، ويكون من حق البائع إذا عدل المشتري عن الثراء.

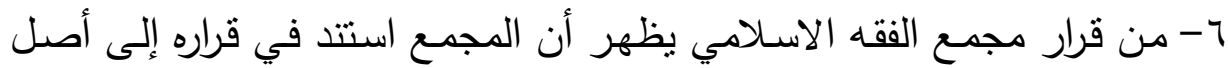

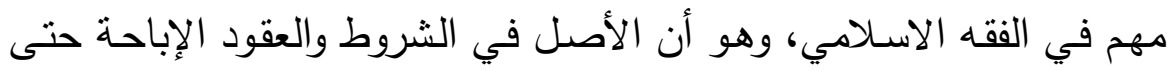
يرد دليل على الحظر، وقد بينته تفصيلا في محله . 
المصادر والمراجع

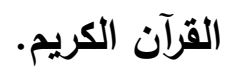

- إعلام الموقعين عن رب العالمين لثمس الدين ابن قيم الجوزية، الطبعة الأولى الكى الكي

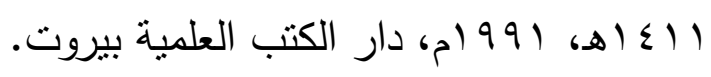

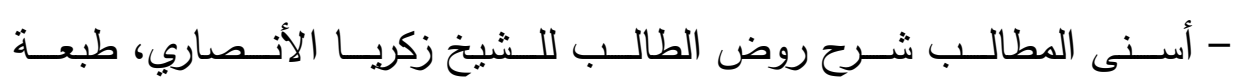
دار الكتب الإسلامي، بدون تاريخ.

- أحكام العربون في الشريعة والقانون للدكتور عبد السلام الترمانيني، بحثب

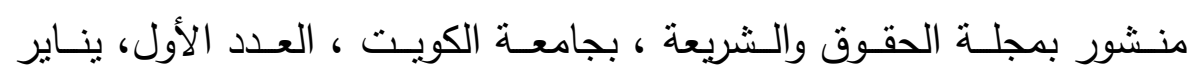

- م) $9 V \mathrm{~V}$

- إحكام الفصول للباجي ، طبعة دار الغرب الإسلامي، بيروت سنة 0 اء اهـ، .01990

- الأعلام لخير الدين الزركلي، الطبعة الخامسة ب919 ام، دار العلم للملايين

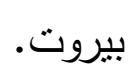

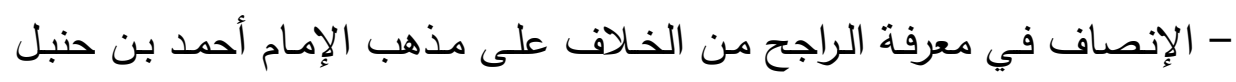
لعلاء الدين أبى الحسن على بن سليمان بن أحمد المرداوي ، طبعة دار الإنهاء إحياء

$$
\text { النراث العربي. }
$$

- التلخيص الحبير في تخريج أحاديث الرافعي الكبير للإمام أحمد بن على بن حجر العسقلاني، طبعة مؤسسة قرطبة.

- تاريخ القانون المصري للدكتور عبد الحميد الحفناوي، طبعة مؤسسة الرسالة

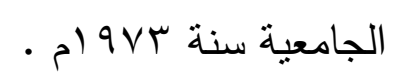

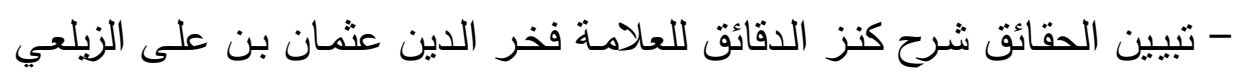

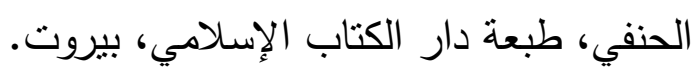

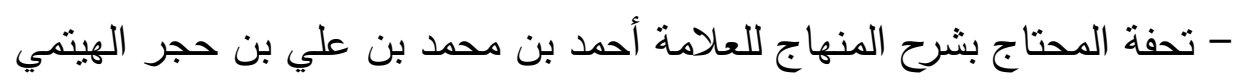

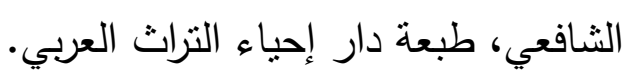


- تذكرة الحفاظ لمحمد بـن طـاهر القيسراني ، الطبعـة الأولى 1 1 ـ اهـ ، دار الصميعي بالرياض.

- تهذيب الكمـال في أسـماء الرجـال لجمـال الدين أبى الحجـاج يوسف المـزى، الطبعة الثانية ب9 99 (م، مؤسسة الرسالة، بيروت، بتحقيق الدكتور بشار عواد

$$
\text { معروف. }
$$

- تهذيب التهذيب لثيخ الإسـام شهاب الدين أبى الفضل أحمد بن على بن حجر العسقلاني الطبعة الأولى ع •ـ اهـ- ع 9 ام، دار الفكر بيروت . - التقات لأبي حاتم محمد بن حبان البستي، الطبعة الأولى 90 بـ أهـ 9 (م، دار الفكر.

- الجرح والتعديل لأبي محمد عبد الرحمن بن أبي حاتم محمد بن إدريس الرازي التميمي البستي، الطبعة الأولى 90 امه، دار إحياء التراث العربي بيروت . - الجـواهر المـضية في طبقـات الحنفيـة لأبـي الوفـاء القرشي، الطبعـة الثانيـة ب99 ام، دار هجر للطباعة والنشر . - حاثية الدسوقي على الشرح الكبير لمحمد عرفة الدسوقي، طبعة دار إحياء

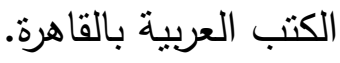

- حاثيتا قليوبي وعميرة على شرح الجلال المحلي للشيخ شهاب الدين بن سـامة القليوبي والثيخ شهاب الدين البرلسي الملقب بعميرة، طبعة دار إحياء الكتب

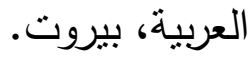

- حكم بيع العربون، للدكتور عبد العزيز بن محمد الربيش، طبعة مركز البحوث الثرعية بجامعة القصيم، الإصدار رقم 7،طبعة سنة ـ بـ اهـ. - حليـة الأوليـاء وطبقات الأصـفياء لأبى نعيم أحمد بـن عبد الله الأصبهاني، الطبعة الرابعة ه . ع اهـ، دار الكتاب العربي بيروت. - الديباج المذهب في معرفة أعيان علماء المذهب لابن فرحون المالكي، الطبعة الأولى VI ا أه- 999 ام، دار الكتب العلمية، بيروت. 


\section{=يع العربون}

- الذخيرة للإمام شهاب الدين أحمد بن إدريس القرافي، تحقيق محمد بو خبزة،

$$
\text { الطبعة الأولى ع } 99 \text { ام، دار الغرب الإسلامي. }
$$

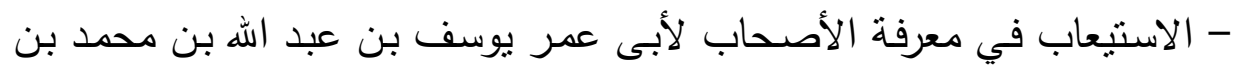
عبد البر، الطبعة الأولى باءع (هـ- بو9 ام ، دار الجيل بيروت. - سنن ابن ماجه للإمام أبى عبد الله محمد بن بزيد بن ماجه القزويني، طبعة الهية

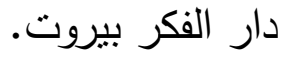

- سنن أبي داود للحافظ أبى داود سليمان بن الأشعث السجستاني الأزدي، طبعة

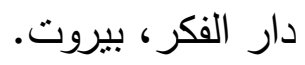

- سنن الترمذي للإمام أبي عيسى محمد بن عيسى الترمذي، طبعة دار إحياء

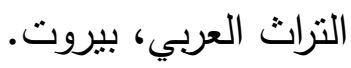

- شـرح الخرشـي على مختصر خليـل لمحمد بـن عبد الله بـن على الخرثـي

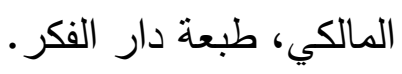

- شرح الزركشي على مختصر الخرقي للشيخ شمس الدين محمد بن عبد الله الزركثي المصري الحنبلي، طبعة مكتبة العبيكان بالرياض.

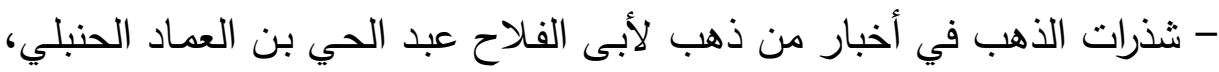
طبعة دار الآفاق الجديدة، بيروت.

- شرح فتح القدير للكمال بن الهمام، طبعة دار الفكر.

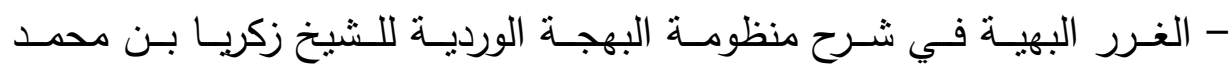
الأنصاري، طبعة المطبعة الميمنية. - القاموس المحيط لمحمد بن يعقوب الفيروزآبادي، تحقيق مكتب تحقيق التراث في مؤسـسة الرسـالة بإنــراف محمـــــــيم العرقسوسي، الطبعـة الـسادسة 9 1§ (اهـ- 999 ام مؤسسة الرسالة بيروت. 
- العربـون بين الفقهـ الإســلامي والقـانون المـني، دراسـة مقارنـة للدكتور ياسـر

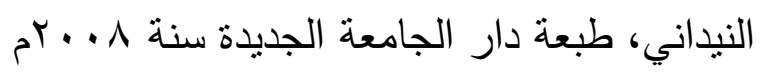

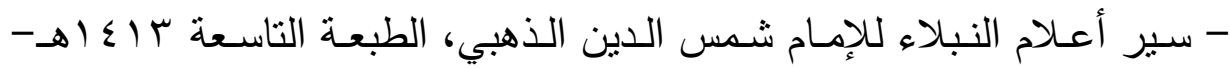

$$
\text { ب9 } 99 \text { (م، مؤسسة الرسالة، بيروت. }
$$

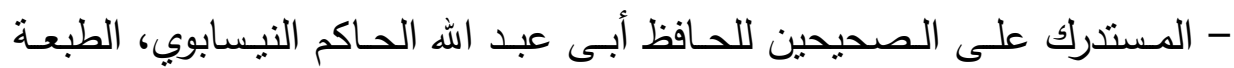
الأولى الإ اهـ- .99 ام، دار الكتب العلمية، بيروت.

- صحيح البخاري للإمام محمد بن إسماعيل البخاري، الطبعة الأولى V • عـ اهـ-

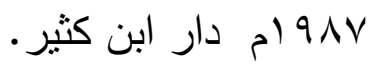

- صحيح مسلم المعروف بالجامع الصحيح للإمـام مسلم بن الحجاج القشيري، الطبعة الثانية rq ب اهـ، دار إحياء التراث العربي، بيروت.

- طبقات الحفاظ للسيوطي جال الدين عبد الرحمن السيوطي، الطبعة الأولى r • ع اهـ ، دار الكتب العلمية، بيروت.

- غمـز عيـون البصائر شـرح الأشباه والنظـائر للسيد أحمد بـن محمد الحنفي

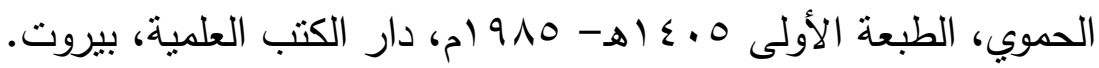
- كثاف القناع عن منن الإقناع لمنصور بن يونس بن إدريس البهوتي، الطبعة الأولى 11 أهـ 99 (م، دار الكتب العلمية.

- المبسوط لشمس الدين محمد بن أحمد بـن أبسى ســل السرخسي، طبعـة دار

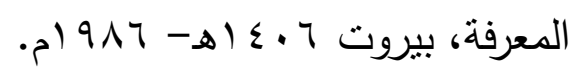

- المجموع شرح المهذب لأبي زكريا يحيى بن شرف النووي، طبعة مكتبة الإرشاد بجدة بدون تاريخ.

- المصباح المنير في غريب الشرح الكبير لأحمد بن محمد بن علي المقري الفيومي، طبعة المكتبة العلمية، بيروت.

- المصنف في الأحاديث والآثار للحافظ أبى بكر عبد الله بن محمد بن أبى شيبه

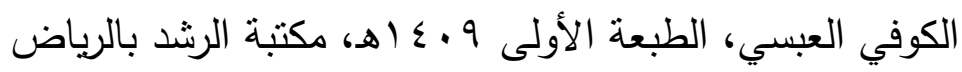




\section{بيع العربون}

- المعجم الوجيز مجمع اللغة العربية بالقاهرة ، طبعة وزارة التربية والتعليم بمصر

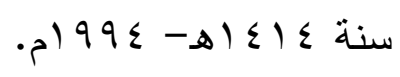

- المعجم الأوسط لأبي القاسم سليمان بن أحمد بن أيوب الطبراني، طبعة دار

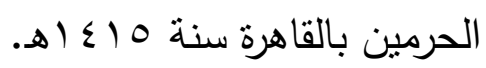

- المعجم الوسيط مجموعـة مـن العلمـاء بإنشراف مجمـع اللغـة العربيـة بالقـاهرة، الصادر عن مجمع اللغة العربية بالقاهرة.

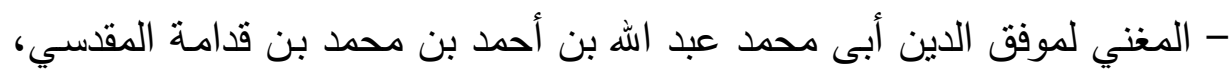

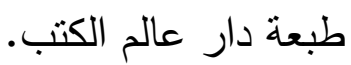

- المنتقى شرح موطأ ماللك لأبى الوليد سليمان بن خلف بن سعد بن أيوب بن وارث الباجي الأندلسي، طبعة دار الكتاب الإسلامي.

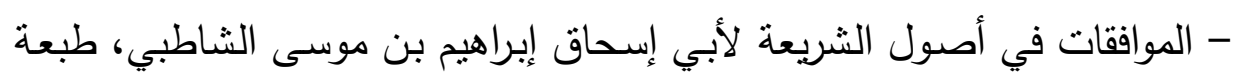

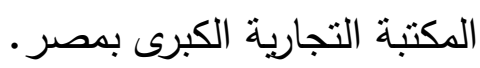

- مجلة مجمع الفقه الإسلامي، أعداد وسنوات مختلفة، تصدر عن مجمع الفقه

$$
\text { الإسلامي الدولي بجدة. }
$$

- مجمع الزوائد ومنبع الفوائد للحافظ نور الدين على بن أبى بكر الهيثمي، طبعة دار الريان للتراث بمصر ، سنة V. •ـ الهـ

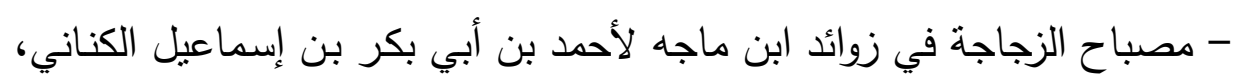

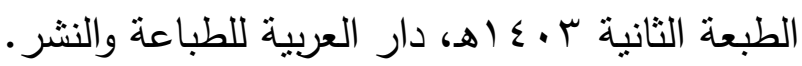

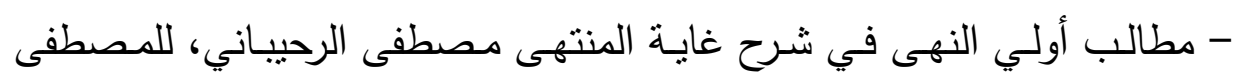

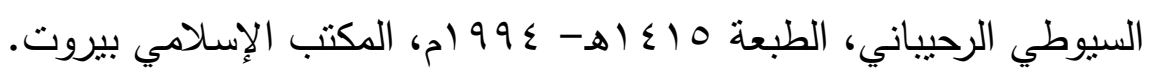

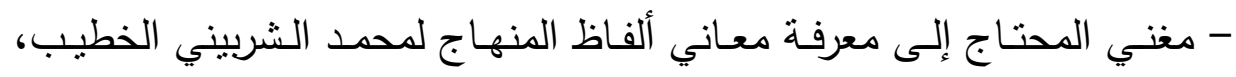

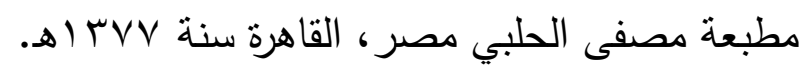


- مواهب الجليل لشرح مختصر خليل لأبى عبد الله محمد بن محمد بن عبد

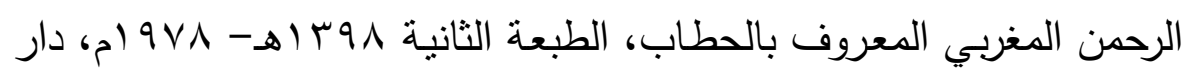

- النهاية في غريب الحديث والأثر لأبى الحسن على بن محمد الجزرى الشهير بعز الدين الأثير، طبعة المكتبة العلمية، بيروت بتحقيق طاهر أحمد الزاوي،

$$
\text { ومحمود محمد الطناحي. }
$$

- النتف في الفتاوى للشيخ علي بن سعيد بن محمد السغدي، تحقيق الدكتور صلاح الدين الناهي، الطبعة الثانية 7 ، ـ اهـ، مؤسسة الرسالة بيروت. - نهاية المحتاج إلى شرح المنهاج لشمس الدين محمد بن أبى العباس أحمد بن حمزة بن شـهاب الدين الرملي المنوفي المصري الأنصاري الثهير بالشافعي الصغير ، طبعة مكتبة ومطبعة مصطفى الحلبي. - وفيات الأعيان وأنباء أبناء الزمان لأبى العباس شمس الدين أحمد بن محمد بن خلكان، طبعة دار صادر ، بيروت. 